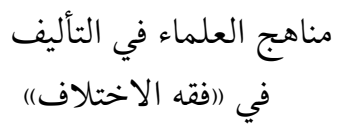

صلاح محمد سالم أبو الحاج

\title{
İhtilaflar Fıkhında Âlimlerin Uzlaştırma Yöntemleri
}

\section{Öz}

İhtilaflar fıkhını, hilâf ilmini ve mukayeseli fıkıhı tanım ve oluşum açısından ayırdım. Fıkıhçıların ihtilaflarının öne çıkan faydalarını zikrettim ve ihtilaflar fıkhı alanında eser yazarken kullanılan altı yöntemi kitap ve fıkhî problem örnekleri ile belirttim. Alanda çalışanların günümüzde ve geçmişte kullanılan eser yazma yöntemini göstermesi için hilâf ilminde kullanılan bir yöntemi, mukayeseli hukukta ise dört yöntemi zikrettim.

\section{Scientists Approaches in Authoring in"Alekhtalaf jurisprudence"}

\section{Abctract}

I have differentiated between "Alekhtalaf jurisprudence", "Alkhelaf jurisprudence" and "Comparative jurisprudence" in terms of definition and upbringing. I mentioned the most benefits to the study of the differences between scholars. I showed six approaches to the formation in the jurisprudence of difference with the representation by a book and an issue in "Alkhelaf jurisprudence". Then I reported an approach in "Alkhelaf jurisprudence", and four approaches in "Comparative jurisprudence" to show the student how authoring is clear between the foregoings and contemporaneouses.

Key words: Alekhtalaf jurisprudence, Alkhelaf jurisprudence, Comparative jurisprudence.

$$
\text { ملخص البحث: }
$$

فرَّقت بين فقه الاختلاف وعلم الخلاف والفقه والمقارن من حيث التعريف والنشأة، وذكرت أبرز الفوائد لدراسة اختلاف الفقهاء، وبيَّنت ستة مناهج للتأليف في فقه اختلاف مع التمثيل عليها بكتاب ومسألة فقهية، وذكرت منهجا واحداً في علم الخلاف، وأربعة مناهج في الفقه المقارن حتى يظهر للدارس طريقة التأليف واضحة بين السابقين والمعاصرين. الكلمات المفتاحية: فقه الاختلاف، علم الخلاف، الفقه المقارن، مناهج فقه الاختلاف فلاف، نشأت الفقه المقارن.

\section{مقدمة}

$$
\text { الحمد لله، و الصلاة والسلام على رسول الله وعلى آله وصحبه أجمعين، وبعد: }
$$

فإنَّ ((علم الاختلاف)) معروفُ مشهورٌ، ولا يبلغ الراغب في الفقه مبلغه حتى يطلع عليه

ويتعرف به، وقد اعتنى أئمة الإسلام به عناية فائقة جداً، فبدأ التأليف فيه منذ القرن الثاني، إذ إذ

* الأستاذ المشارك في جامعة العلوم الإسلامية العالمية، كلية الشريعة والقانون، الأردن، عمان، 2015م، الإيميل: salahhaj74@yahoo.com، التلفون: 00962785455906 
قام بعض الأئمة بجمع آثار الصحابة والتابعين وخلافهم في المسائل في مصنفات حديثية، ثُمَّم تطوّر هذا العلم في عهد الأئمة المجتهدين فبدأوا يذكرون المسألة الفقهيّة والخلاف فيها...' . واشتهرت الطريقة المعاصرة في المقارنة بين المذاهب ـ بالتلفيق بين الأحكام بالمزج بين أقو ال الفقهاء بدون ضو ابط، والاختيار والترجيح بدون أصولٍ معتبرة ولا دراية كافية ..

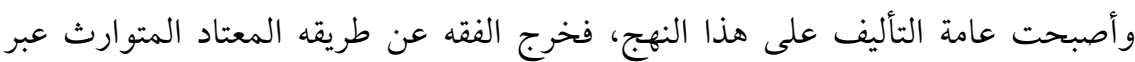
القرون المقرَّرة في مذاهب فقهية معتبرة، فانعكس سلباً على الشرق والغرب بانتشار أفكار وفتاوي شرعية إسلامية غير منظبطة، وخرجت جماعات واتجاهات تحمل منهجاً مستغرباً، كما يلاحِظظ مَن ينظر للمسلمين في هذا الزمان. فكانت أهمية البحث بييان عرض تاريخي لطريقة عرض الاختلاف والمناهج التي سلكت فئت فئس فيه، حتى يتميّز لنا حقيقة المشكلة التي وقعت؛ إذ الأصل في التأليف الفقهي هو الطريق

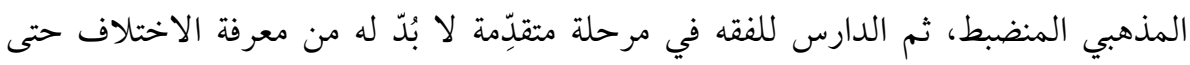
يستفيد من المذاهب الأخرى ولا يتعصب ولا يتشدّد. قال الغَزَالي : "رينبخي أن يحترزَ الخائض في العلم في مبدأ الأمر عن الإصغاء إلى اختلاف الناس، سواء كان ما خاض فيه من علوم الدنيا أو من علوم الآخرة، فإنَّ ذلك يدهش عقله

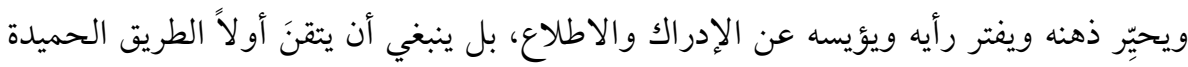

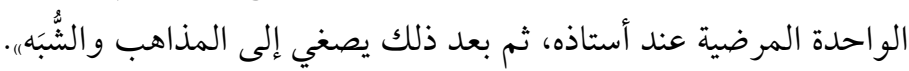
ونريد أن يرتفع الخلط بين ما سار عليه السابقون من ((فقه الاختلاف))، وبين ما ظهر في إسي هذا العصر باسم: ((الفقه المقارن)). وتكمن مشكلة البحث في الإجابة عن الأسئلة الآتية: هل هناك فرق بين ((فقه الاختلاف)) و ((علم الخلاف)) و (الفقه المقارن)). وما فائدة دراسة علم الاختلاف؟ وما هي المناهج المتبعة في التأليف ((فقه الاختلاف)) و ((علم الخلاف)) و (الفقه المقارن)). وما هي الطريقة التي ينبغي علينا أن نتبعها حتى ننعم بالاستقرار الفكري والفقهي، ونتخلص من التخبط والجهل الذي أصبحنا نعيش فيه؟

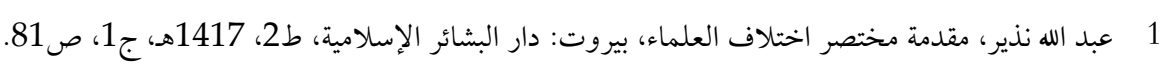
2 
واتبعتُ في بحثي المنهج الاستقرائي من كتب التاريخ والطبقات بجمع الكتب المؤلفة في

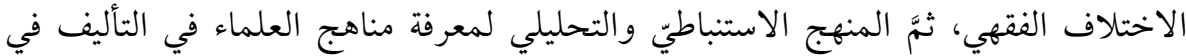

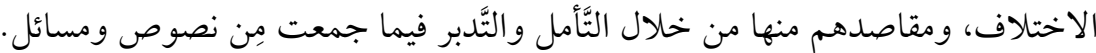

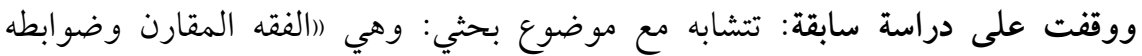
وارتباطه بتطوَّر العلوم الفقهية خلال القرن الخامس الهجري" للأستاذ الدكتور محمد فالعد

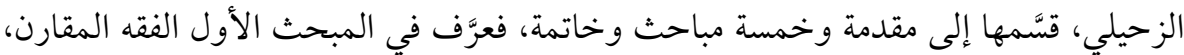

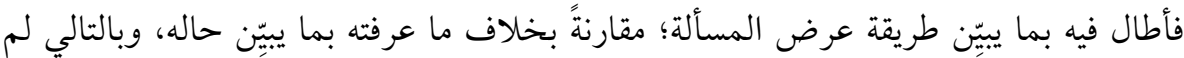
يأت بتعريف منضبط صحيح يمكن التعويل عليه.

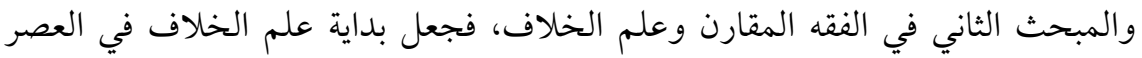

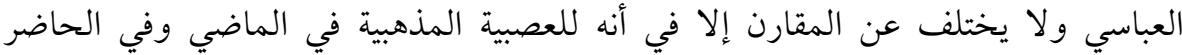

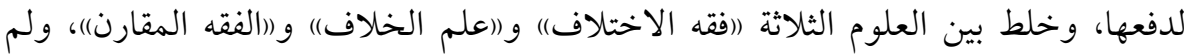

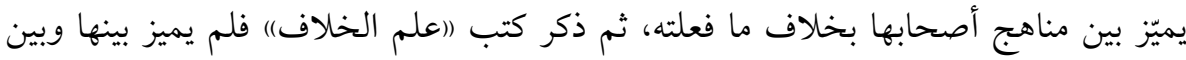

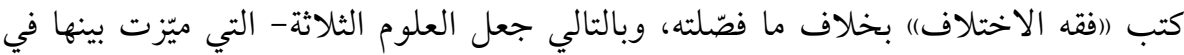
البحث- علماً واحداً، ويترتب على هذا آثاراً سلبية عديدة.

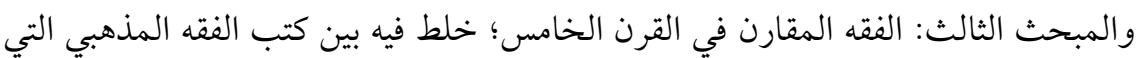

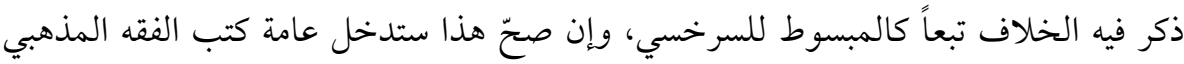

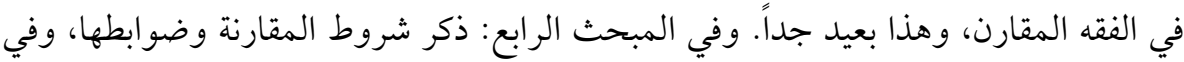

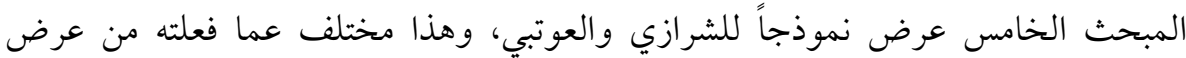

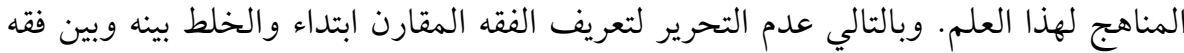

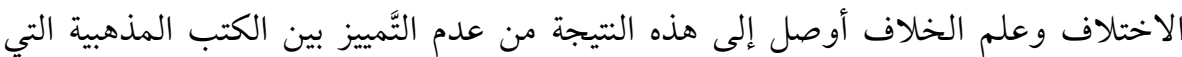

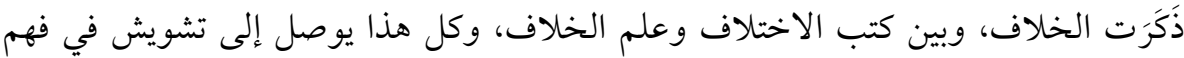
هذه العلوم الثلاثة، والله أعلم. ولتحقيق المقصود من البحث، رأيت تقسيمه إلى تمهيد وثلاثة مباحث وخاتمة: فالتمهيد في مطلبين: المطلب الأول: في تعريف مفردات مناهج العلماء في التأليف في فقه الاختلاف.

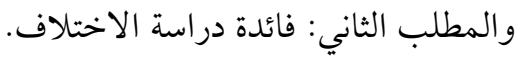

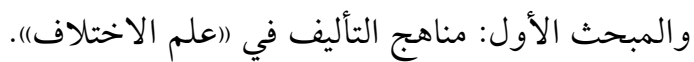

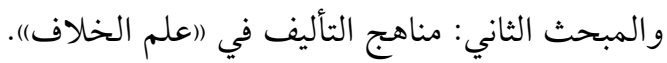
والمبحث الثالث: مناهج التأليف في ((الفقه المقارن). 
المطلب الأول: في تعريف مفردات مناهج العلماء في التأليف في فقه الاختلاف:

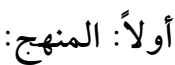

لغةً: قال ابن فَارِس: (النون والهاء والجيم أصلان متباينان: الأَوَّل: النهج: الطريق، ونَهَج

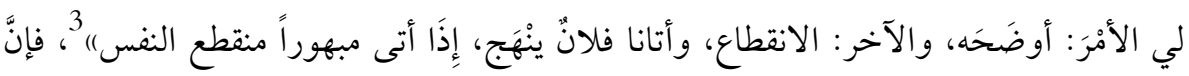

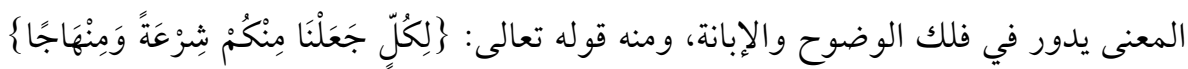
المائدة: 1 §، ومعنى منهاجا: طريقاً واضحاً

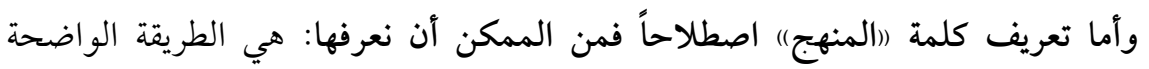
المسلوكة التي ابتكرها المؤلف للالتزام بالمتابعة.

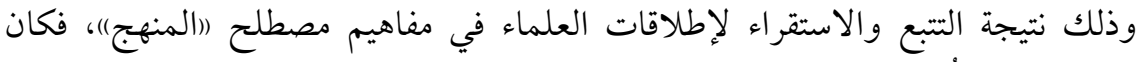

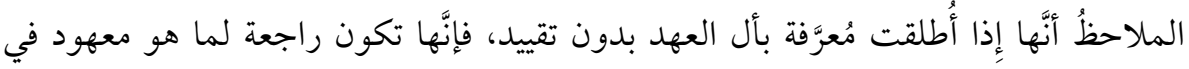

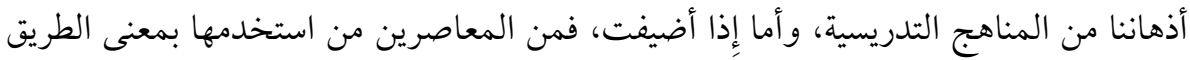

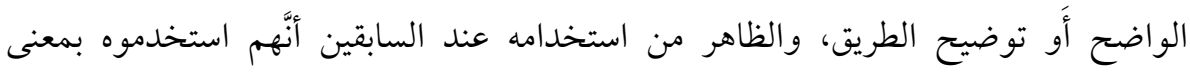

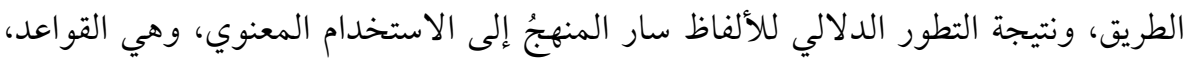

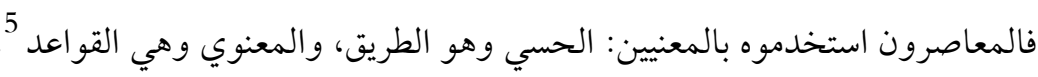
ثانياً: الفقه: لغةً: هو الفهم مطلقاً، وهو ما يدلُ على إدراكِ الشيء، والعلم به، والفهم له .6. اصطلاحاً: له معنيان عند الفقهاء والأصوليين:

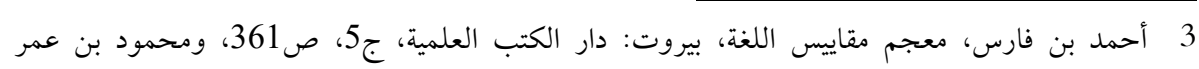

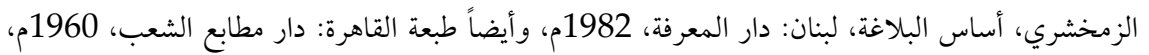

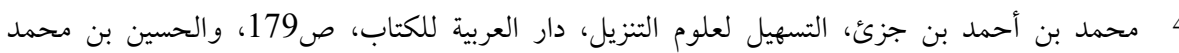

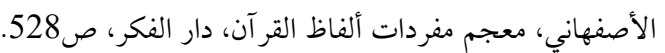

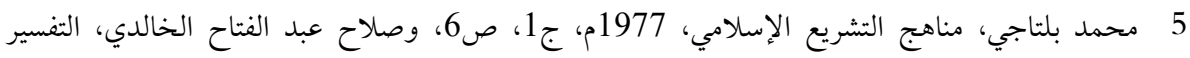

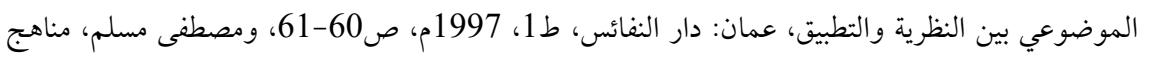

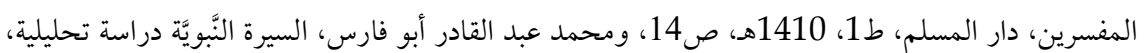

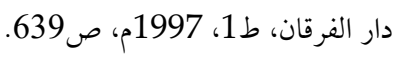
6 6 الأصفهاني، معجم مفردات ألفاظ القر آن، ص398، م39، وابن فارس، معجم مقاييس اللغة، ج4، ص442. 
فإنَّ أصحاب كلّ علم ينظرون إلى المعنى من الجانبِ الذي يخدم علمهم، فالأصوليّون

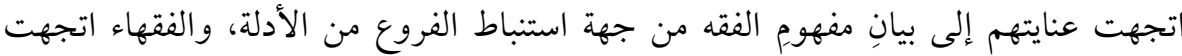
عنايتهم بالفقه من جهة التطبيق على المكلّفين.

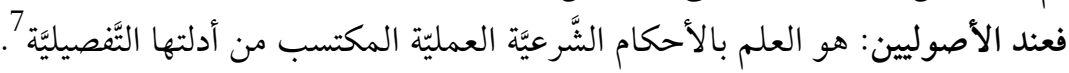

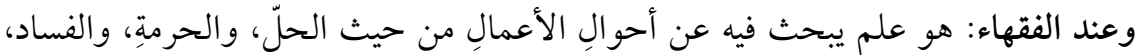
والصِّحة.

وعرفه أبو حنيفة: معرفة النفس ما لها وما عليها عملاً.

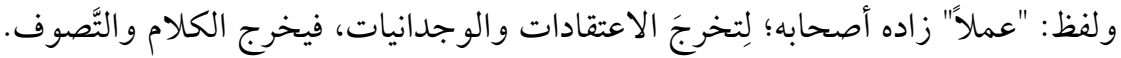

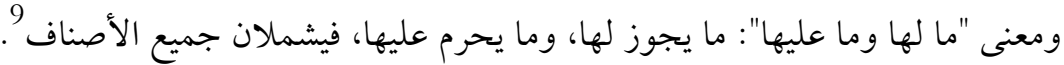

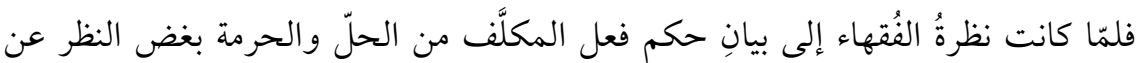
الدليل، اهتموا بتعريف الفقه من هذه الحيثّة.

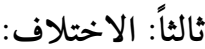

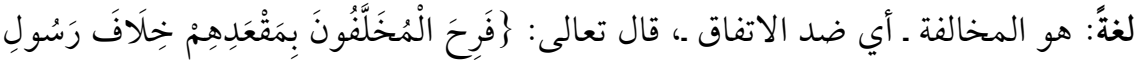
اللهّهُ التوبة: 1 أي: مخالفة رسول الله 10. واصطلاحاً: فقه الاختلاف: هو علم يبحث في أقوال الفقهاء قصداً سواء كانت بأدلتها ونقض قول المخالف أم لا. فهو علمُ يهتمّ بذكر خلاف الفقهاء مقصوداً في التأليف؛ إذ عامّة كتب الفقه تعرج أحياناً

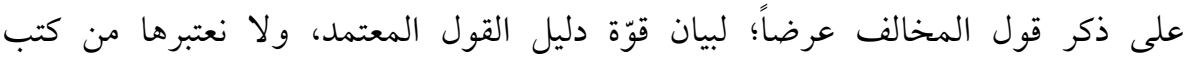

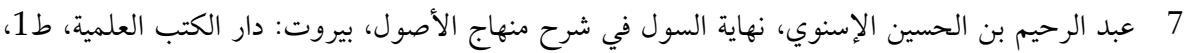

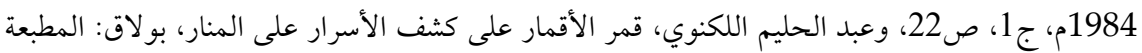

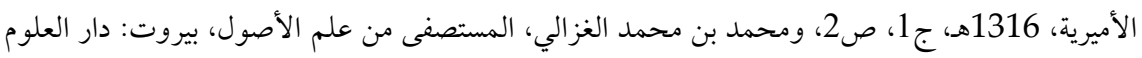

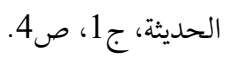

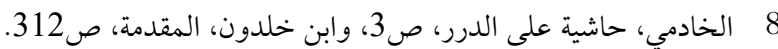

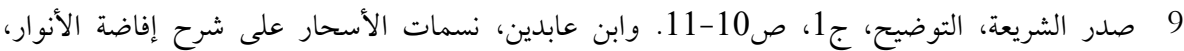
ص10

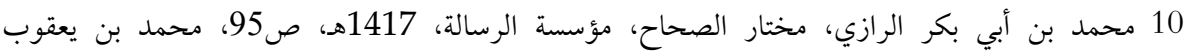

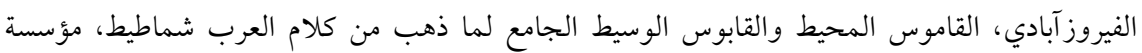

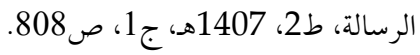


الاختلاف، بخلاف ما يكون المقصود منها ابتداءً ذكر أقوال العلماء في المسألة، سواء اقتصر

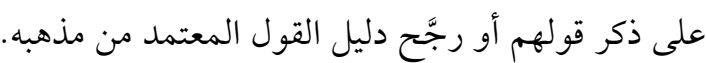

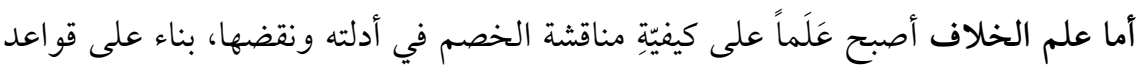

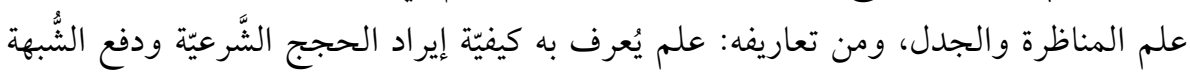

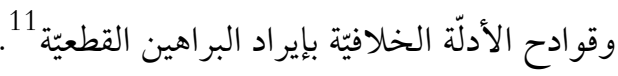

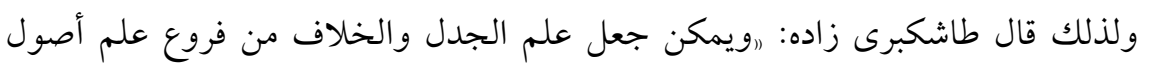

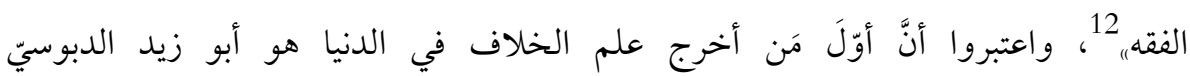

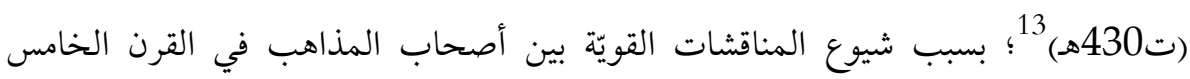

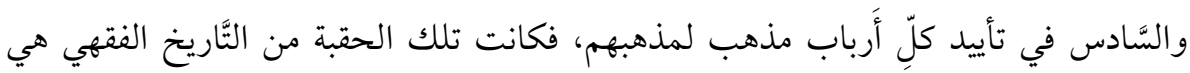

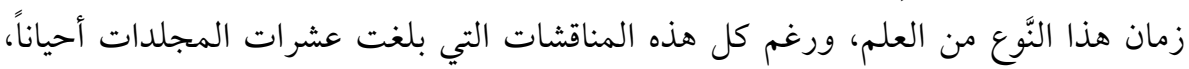

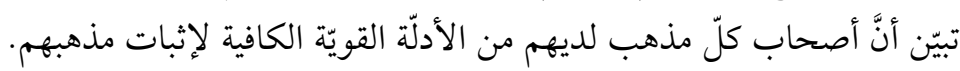

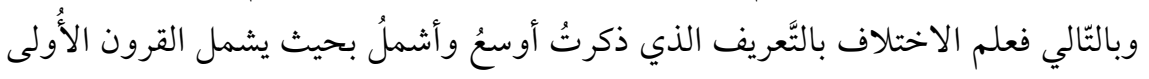

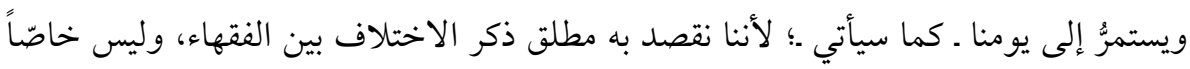
بنقض قول المخالف.

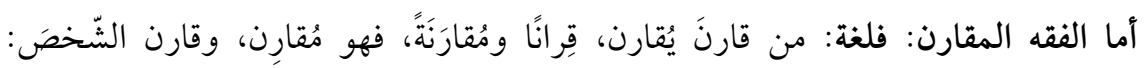

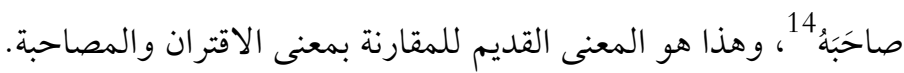

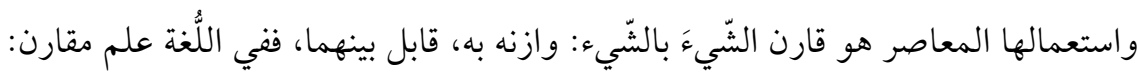

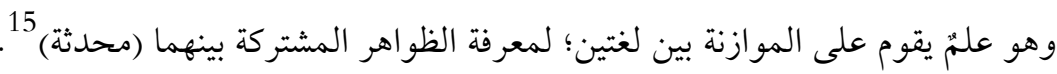

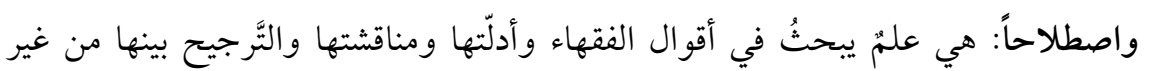
أرباب المذاهب وبدون اعتماد على "أُصولهم.

11 محمد بن الحسيني الزبيدي، إتحاف السادة المتقين بشرح إحياء علوم الدين، بيروت: مؤسسة التاريخ

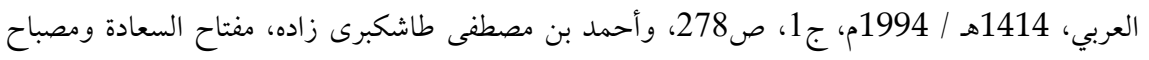

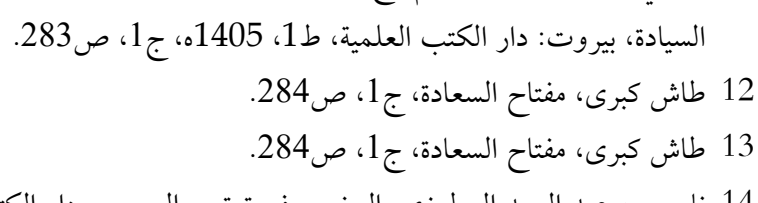

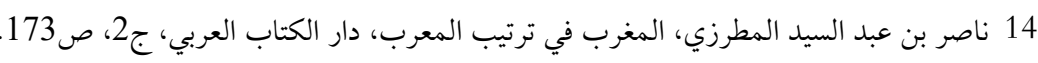

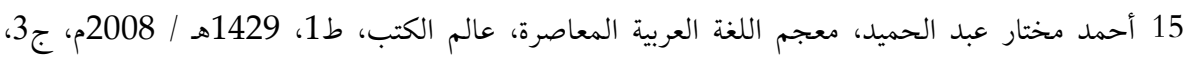

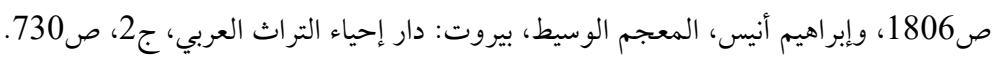


وبالتّالي أبرزُ ما يُميّز هذا العلم عن فقه الاختلاف عدم التّرجيح بين مسائله بأصوله معتبرة

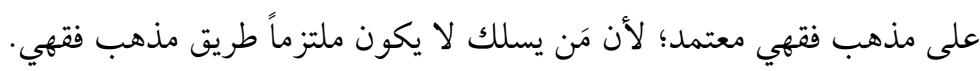

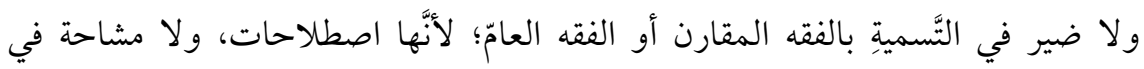

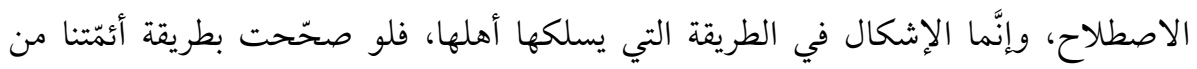

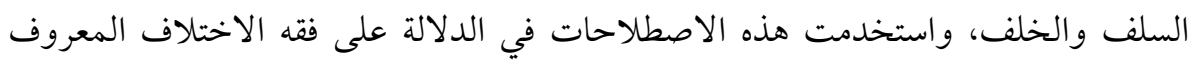
فلا إشكال.

وتبيَّن لنا من التعاريف السابقة أن بين يدينا ثلاثة علوم: ((فقه الاختلاف)) و (اعلم الخلاف) و ((الفقه المقارن).

فققه الاختلاف نشأته مع نشأة الفقه؛ لأنّه جزء من تركيبه، ولا يتحقّق الفقه بدونه، فبدأ

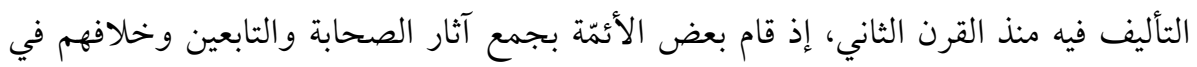

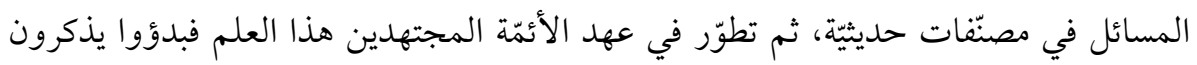
المسألة الفقهيّة والخلاف فيهائ 16، ومن كتبه:

$$
\text { اختلاف الصحابة: لأبي حنيفة (ت150هـ) } 17
$$

اختلاف الفقهاء: لأبي بكر الطبريّ اللؤلؤيّ الحنفيّ من أصحاب محمد بن بن شجاع . 18 (ت266)

$$
\text { كتاب الاختلاف: لأبي عبد الله محمد بن عمر الواقديّ (ت2960هـ). }
$$

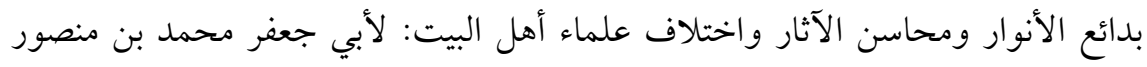

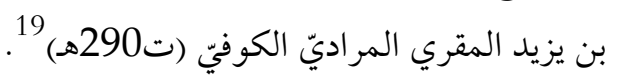

اختلاف الفقهاء: لأبي إسحاق إبراهيم بن جابر المروزيّ الشافعيّ (310هـ) 20. قال الخطيب البغداديّ 21: (له كتاب مصنّف في اختلاف الفقهاء جمّ المنافع، كثير الفوائد).

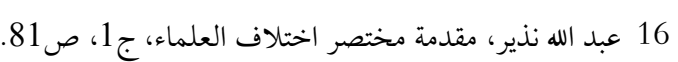

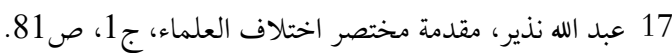

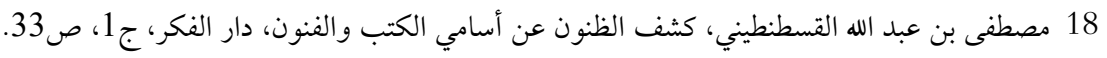

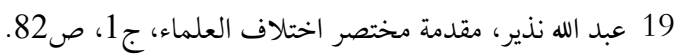

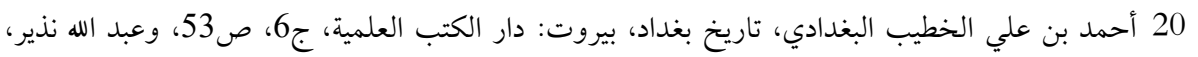

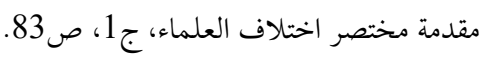

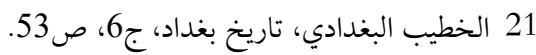


الإشراف على مذاهب العلماء، واختلاف العلماء: لأبي بكر محمد بن إبراهيم بن المنذر

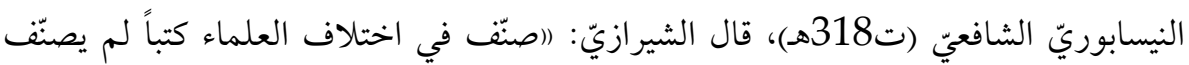

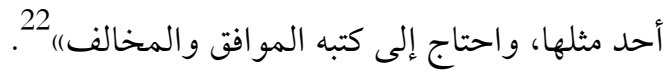

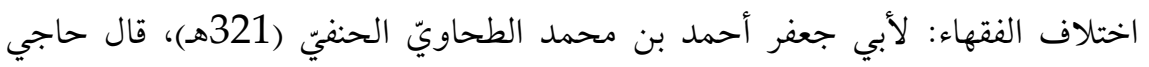

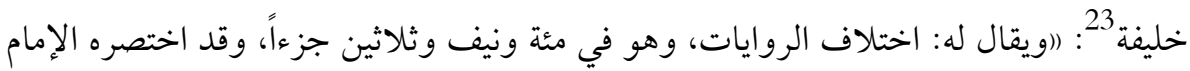
أبو بكر الجصّاص الحنفيّ (ت370هـ).).

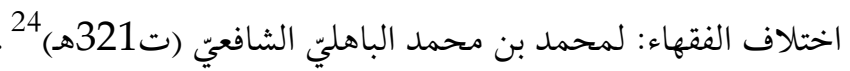

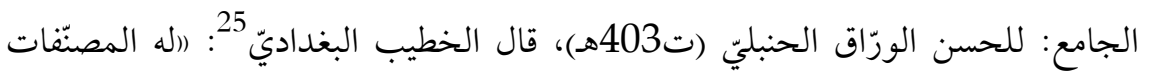

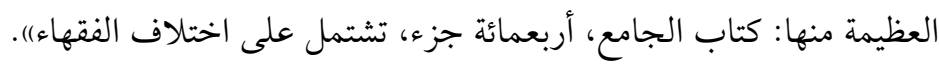

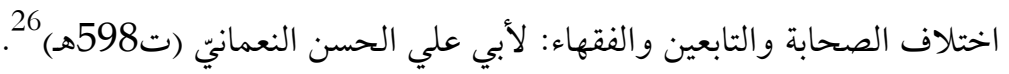

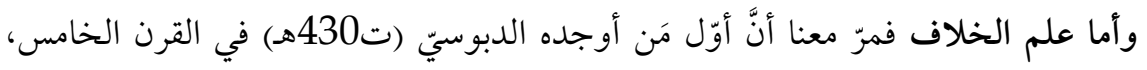
وكثرت التأليفات فيه، ومنها:

تحفة النبهاء في اختلاف الفقهاء: لأبي عبد الله محمد الدمشقيّ الشافعيّ (ت705هـ)

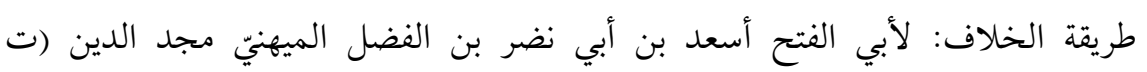

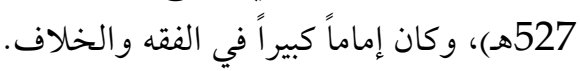

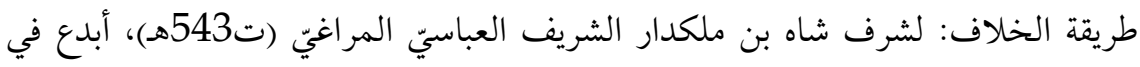
الفقه حتى صار من أنظر الفقهاء 28.

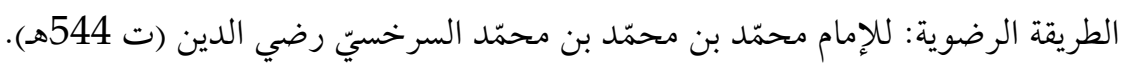

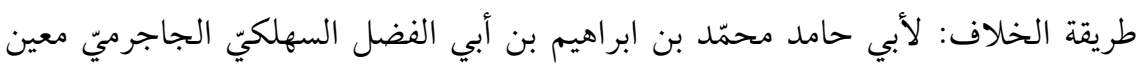
الدين (ت613هـ)، قال ابن خلكان: (اكان إماماً فاضلاً متفنتاً مبرزاً).

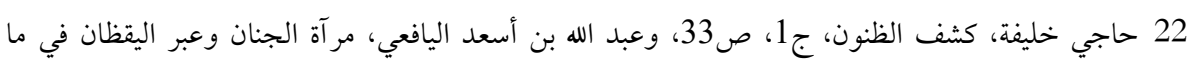

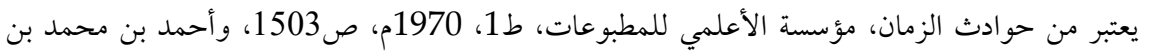

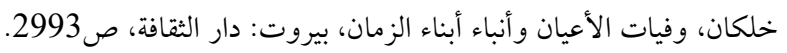

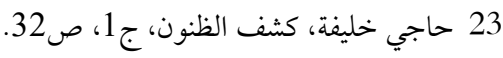

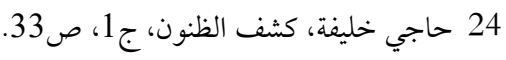

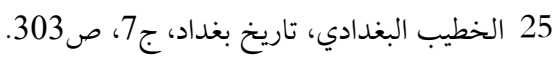

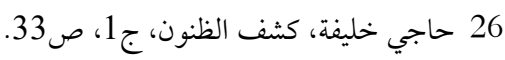

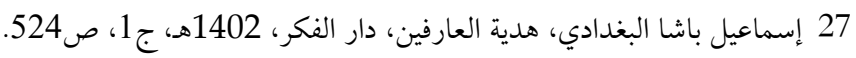

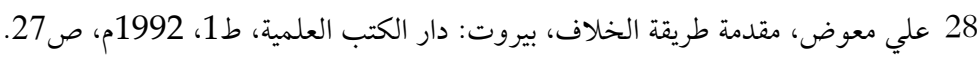


الطريقة العميدية في الخلاف والجدل: لأبي حامد محمّد بن محمّد بن محمّد العميديّ

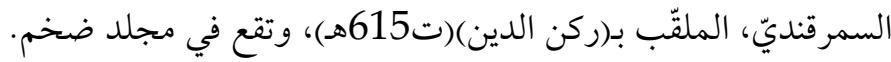

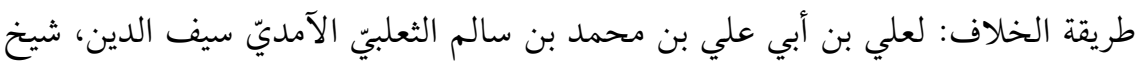
المتكلّمين في زمانه ومصنف الأحكام (ت حسنة". الطريقة الحصيريّة في علم الخلاف بين الحنفيّة والشافعيّة: لأبي حامد محمود بن أحمد

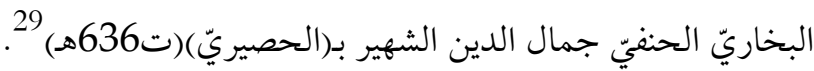

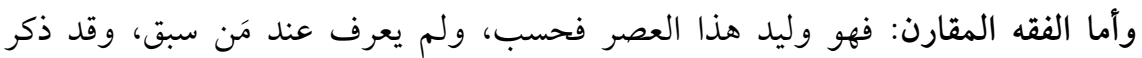

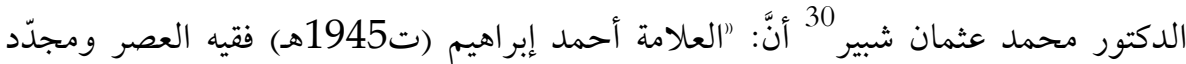

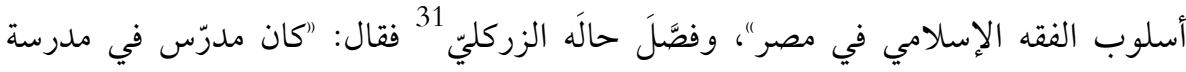
القضاء الشرعي ثم في كليّة الحقوق ... امتاز بأبحاثه في المقارنة بين المذاهب والشئ والشرائع، له

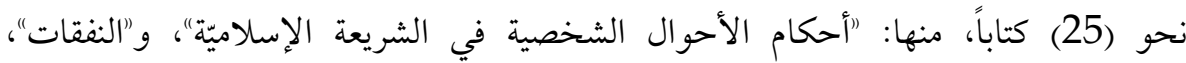

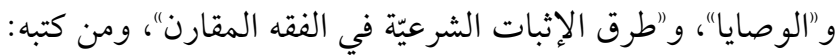
1.مقارنة المذاهب لمحمد علي السايس.

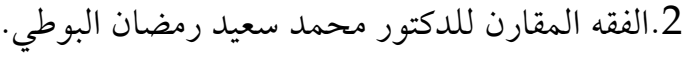

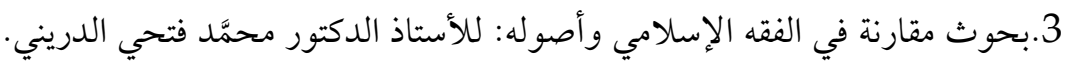
المطلب الثاني: فائدة دراسة الاختلاف: تأكيداً على أهمية علم الاختلاف، نبين الفوائد من دراسته، ونذكر شئلاف الأل من فضله وثناء العلماء على دارسيه في النقاط الآتية:

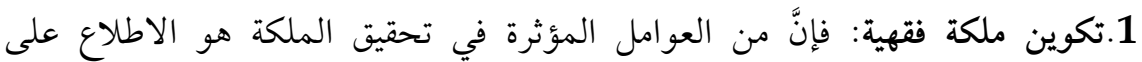

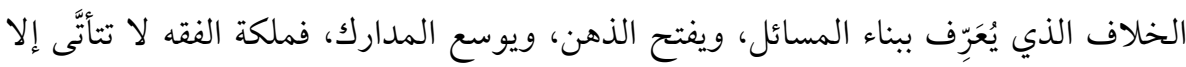

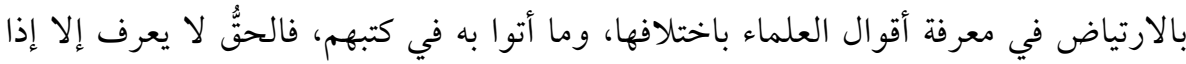

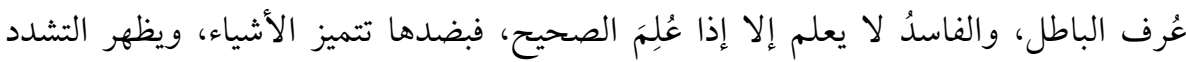

29 علي معوض، مقدمة طريقة الخلاف، ص27.

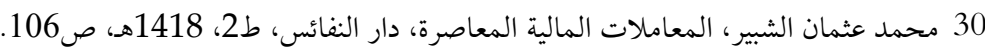

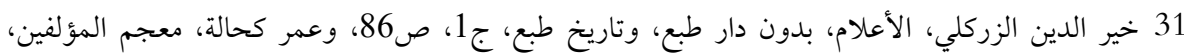

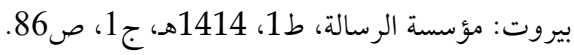


عند من ألِف قولاً واحداً فتبّى حتى كهل عليهُ32، قال ابن أبي عروبة: "رمَن لم يسمع الاختلاف فلا تعدُّوه عالماً "33.

2.إيجاد ثروة فقهية ضخمة: فمن آثار الآراء الفقهيَّة تكونت المدارس الفقهيَّة، ثم تبلوُرها

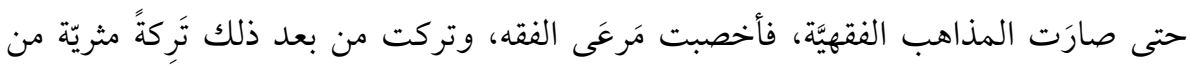
الدراسات الفقهيَّة، لا نكون مُغالين ولا متجاوزين المعقول إذا قلنا: إنَّها أعظم ثروة فقهية في

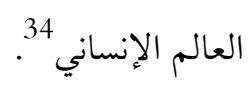

3.التَّوسعةُ على الأمة في العمل: فمعلومٌ أنَّ الاستفادة من المذاهب الفقهية المعتبرة

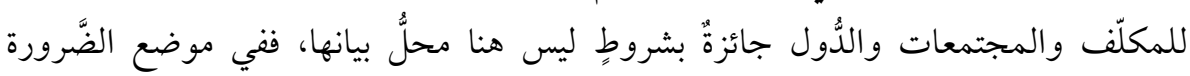
يجوز لنا العمل بمذهب الغير؛ لاجتماع دليل الضرورة مع أدلّة الغير، فيتقوَّى على مذهبنا في حَقّ هذه المسألةِ فجاز العمل به، وهذه توسعة كبيرة على الأمة، فروي عن رسول الله صلى الله عليه وسلم: (اختلاف أمتي رحمة)" 35. 4.دفع الشكوك حول عظم بناء المذاهب، وقوة أدلتها: فمن لا يطالح كتب الخلاف، وينظر في أدلة الموافق والمخالف، يبقى في قلبه تشكك في بناء هذه المذاهب على أدلة قوية،

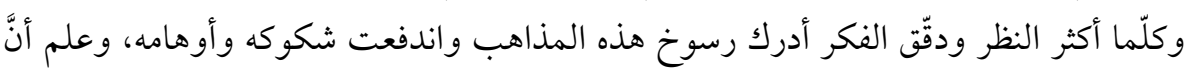

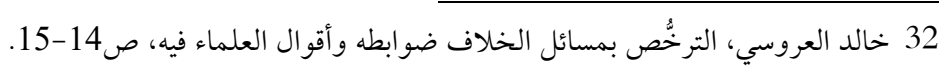

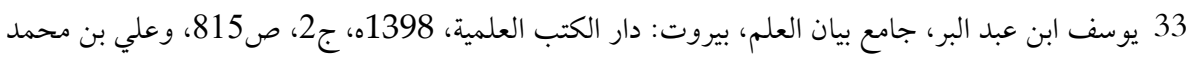

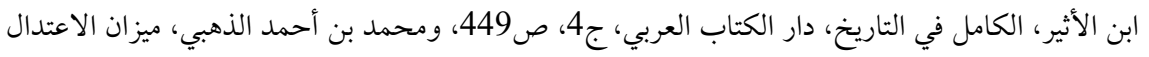

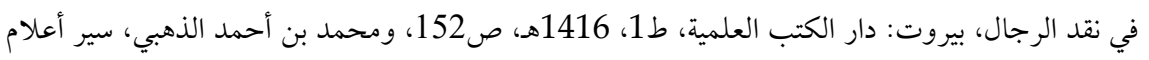

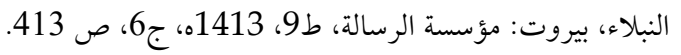

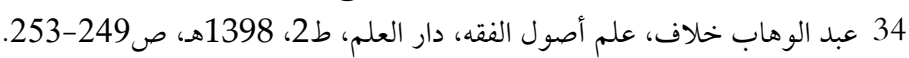

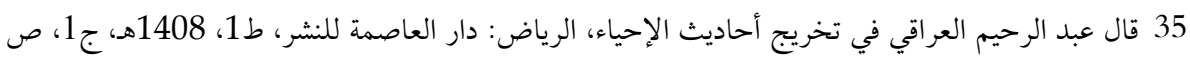

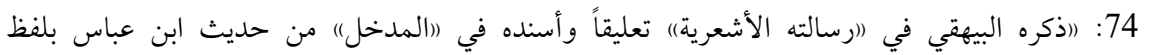

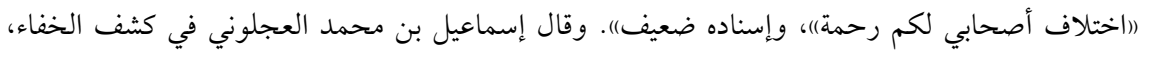

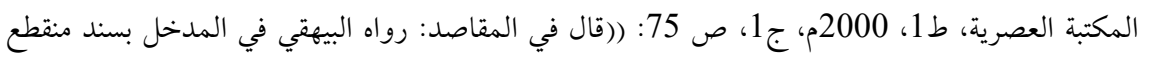
عن ابن عباس بلفظ: قال رسول الله

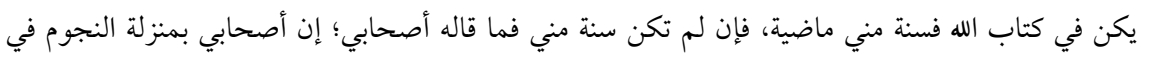

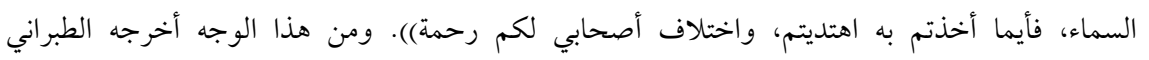

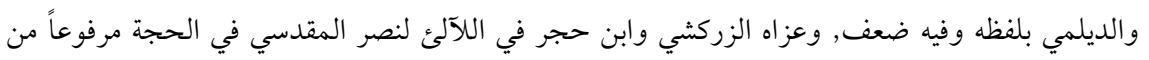

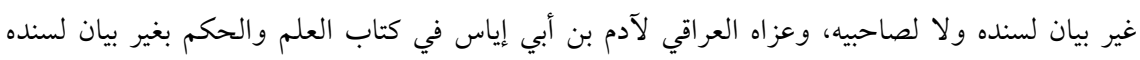

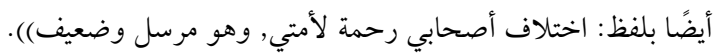


لكل منها أصو لاً بُنيت عليها هذه الفروع، قال طاشكبرى 36": روغرضُ علم الخلاف تحصيل

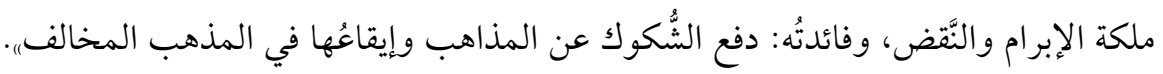

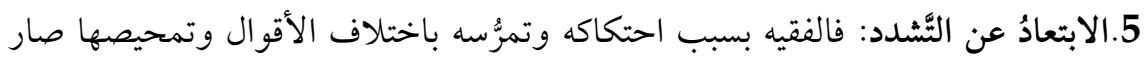

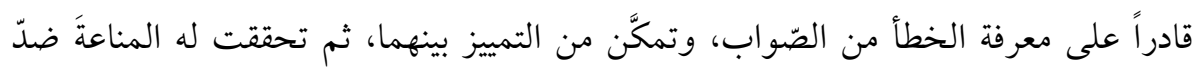

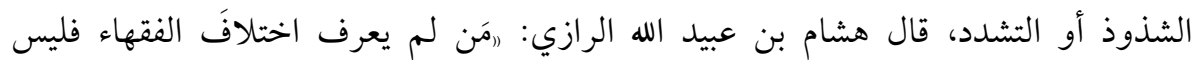

المبحث الأول: مناهج التأليف في (اعلم الاختلاف)؛:

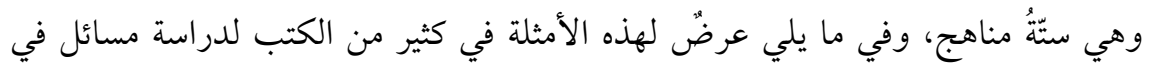
فقه الاختلاف بمناهج مختلفة في الكتابة، ومن هذه الكتب لئي:

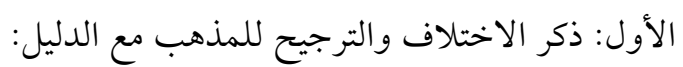

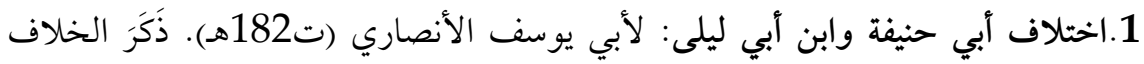

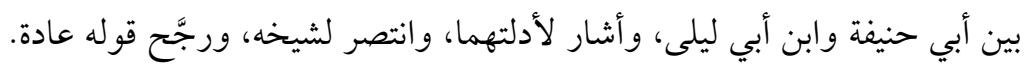

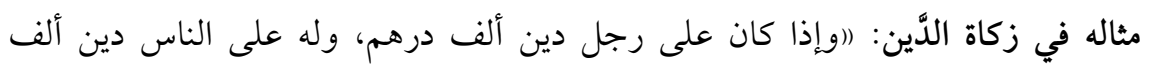

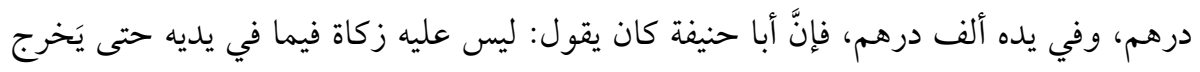
دينه فيزكيه. وكان ابن أبي ليلى يقول: عليه فيما في يديه الزكاة.

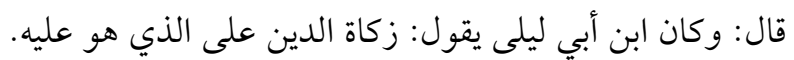

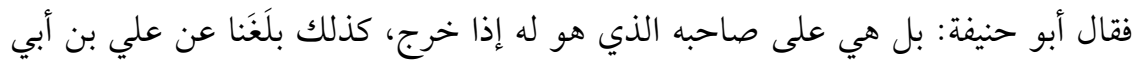
طالب، وبهذا نأخذ)، 2.الرد على الأوزاعي: لأبي يوسف يعقوب الأنصاريّ (ت182هـ). ذَكر فيه الخلاف بين أبي حنيفة والأوزاعيّ، ورد أدلة الأوزاعي، وانتصر لشيخه ألبي لوني حنيفة.

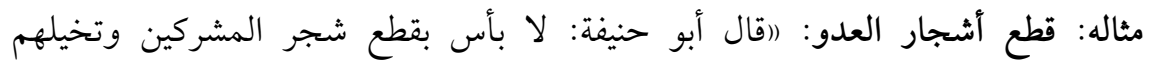

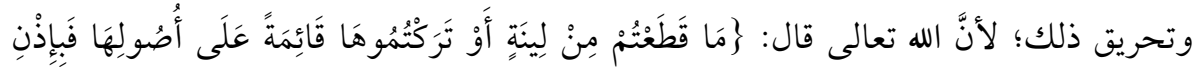

$$
37 \text { ابن عبد البر، جامع بيان السعادة، ج1، ص283، ص283. }
$$

38 يعقوب بن إبراهيم الأنصاري، اختلاف أبي حَنيفة وابن أبي ليلى، الهند: لجنة إحياء المعارف النعمانية، ط137،

ج1، ص122-123. 
اللَّهُ الحشر: 0، وقال الأوزاعي: أبو بكر يتأول هذه الآية، وقد نهى عن ذلك وعمل به أئمة المسلمين.

قال: (المّا بعث أبو بكر خالد بن الوليد إلى طليحة وبني تميم، قال: أي واد أو دار غشيتها

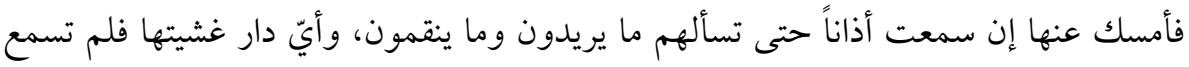

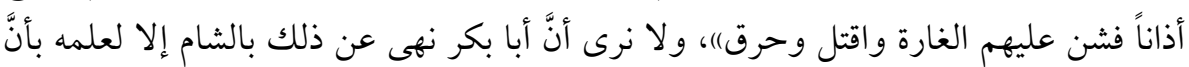

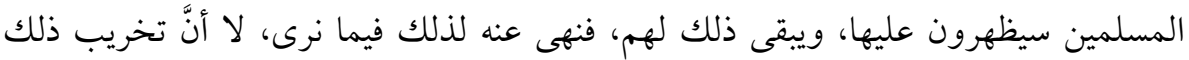

$$
\text { وتحريقه لا يحلّ، ولكل من مثل هذا توجيه. }
$$

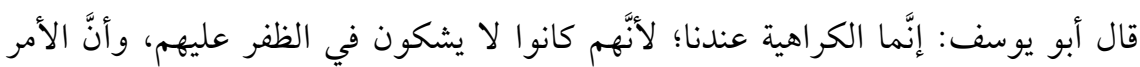

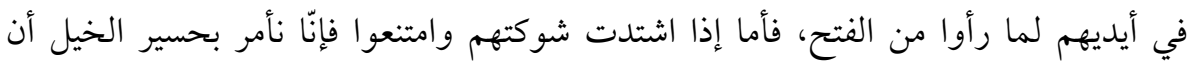

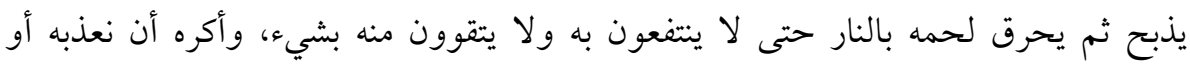

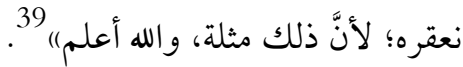

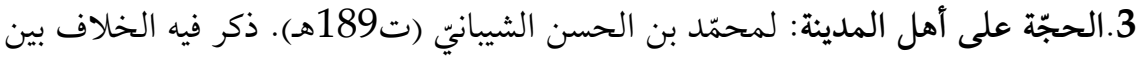

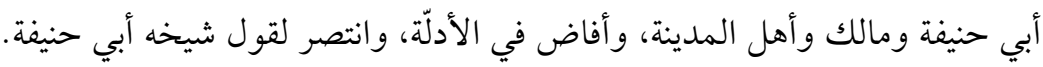

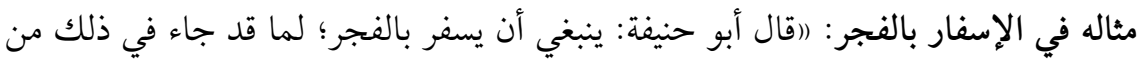

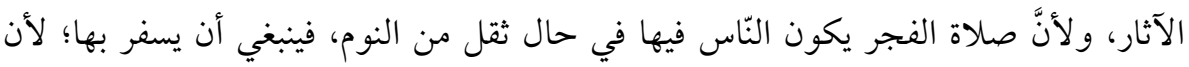

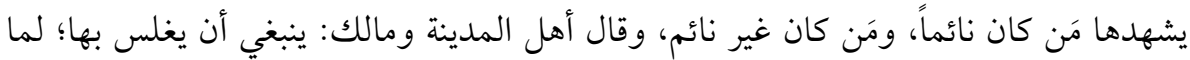

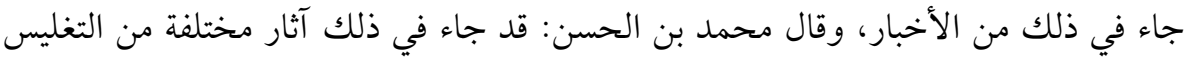

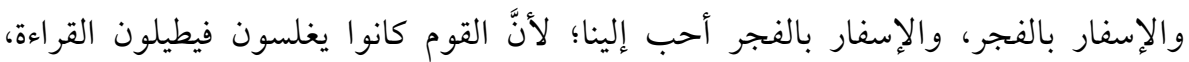

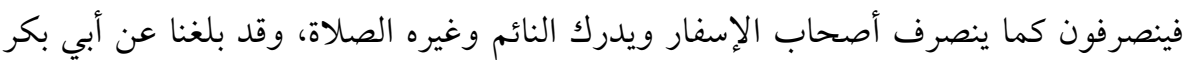

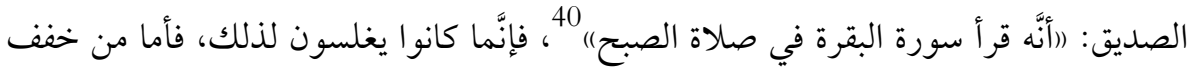

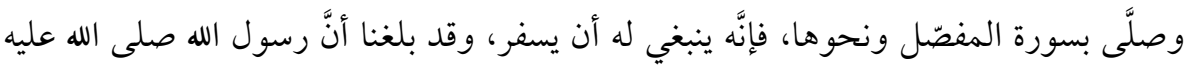

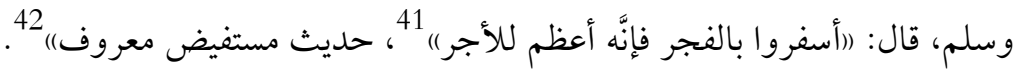

39 يعقوب بن إبراهيم الأنصاري، الرد على سير الأوزاعي، الهند ـ حيدر آباد الدكن: لجنة إحياء المعارف النعمانية، ط1، ص89.

40 أحمد بن محمد بن سلامة الطحاوي، شرح معاني الآثار، بيروت: دار الكتب العلمية، ط1، 1399هـ، ج1، ص182.

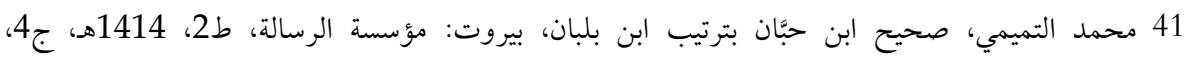

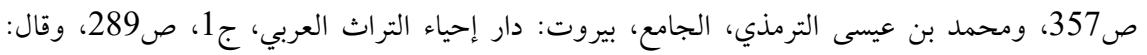


4.عيون الأدلة في مسائل الخلاف بين فقهاء الأمصار: لأبي الحسن علي بن عمر بن

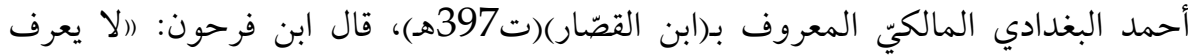

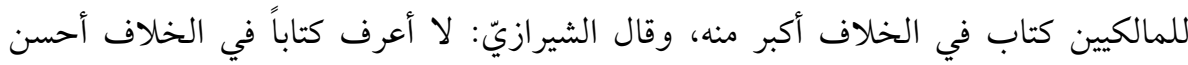
منه)|"43. ذكر مذهب مالك ومَن وافقه ومَن خالفه واستفاض بذكر أدلّة مذهبه.

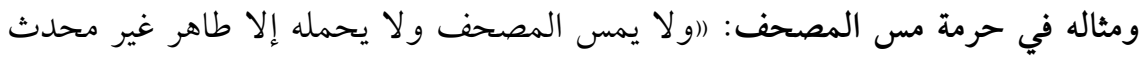

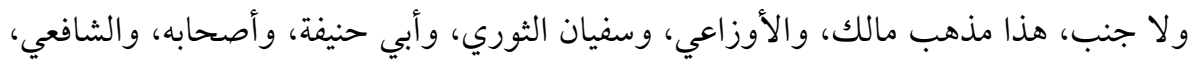

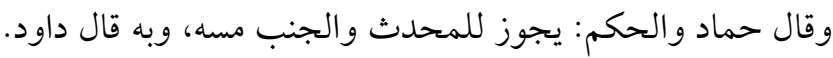

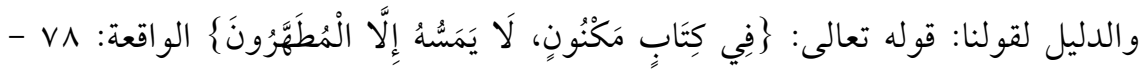

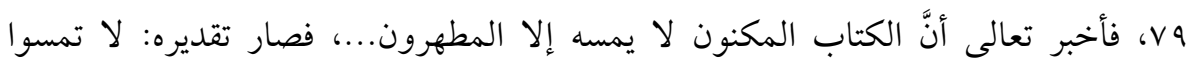
المصحف إلا وأنتم مطهرون. ولنا من السنة: ما رواه عمرو بن حزم أنَّ رسول الله صلى الله عليه وسلم كتب له كتاباً إلى له

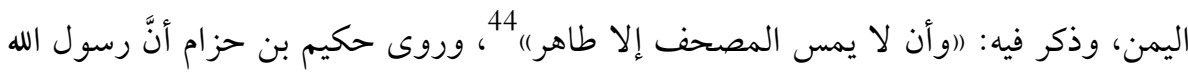

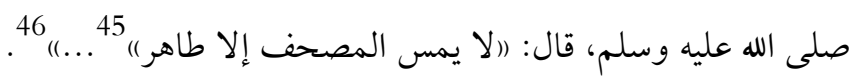

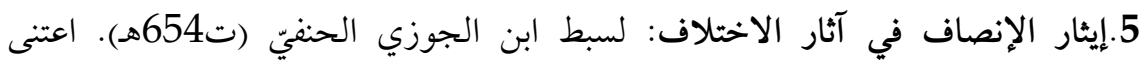

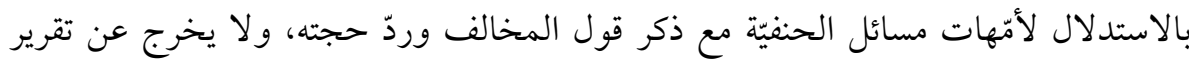
قول الحنفيّة، والله أعلم.

حسن صحيح، وأحمد بن شعيب النسائي، السنن الكبرى، بيروت: دار الكتب العلمية، ط1، 1411هـ، ج1، ص478. 42 محمد بن الحسن الشيباني، الحجة على أهل المدينة، بيروت: عالم الكتب، مصورة عن طبعة لجنة إحياء

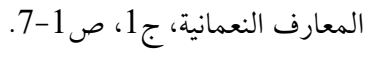
43 علي معوض، مقدمة طريقة الخلاف، ص26.

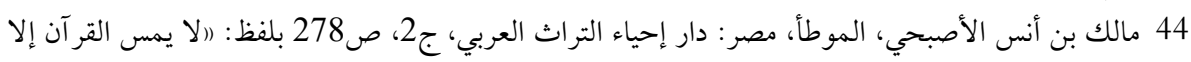

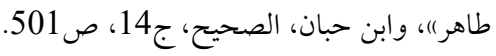

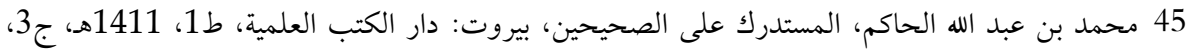

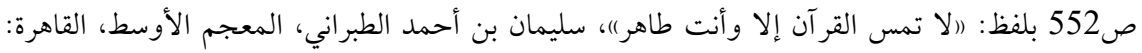

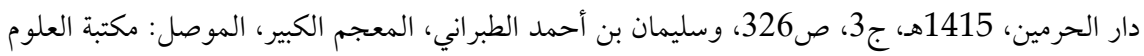

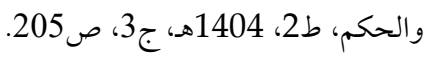
46 علي بن عمر بن القصار، عيون الأدلة في مسائل الخلاف بين فقهاء الأمصار، 1426هـ/234 صـا2006م، ج1، 
ومثاله في ضمان المنفعة: (امسألة: المنافع لا تضمن بالغصب والإتلاف، وهو قول مالك،

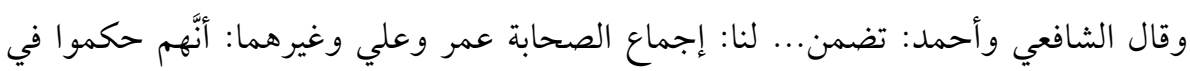

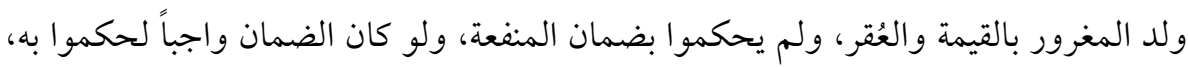

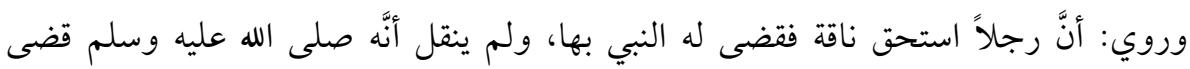
بوجوب الأجر.

فإن قيل: التمسك بالإجماع لا يصح؛ لأنَّهم حكموا بوجوب القيمة والعُقر، وسكتوا عن

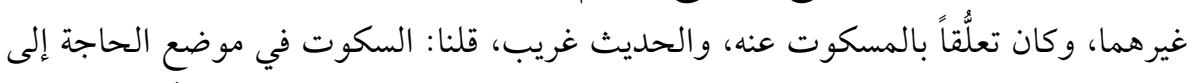

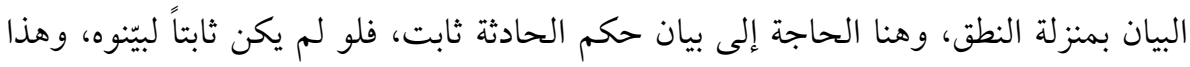

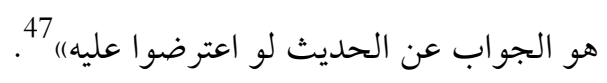$$
\text { الثاني: ذكر الاختلاف بدون ترجيح ولا استدلال: }
$$

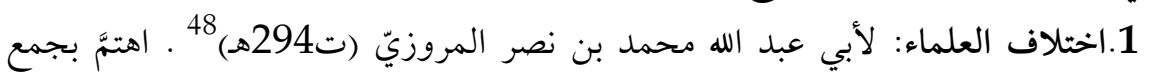

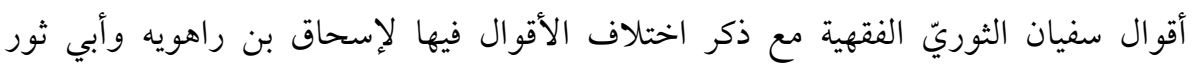

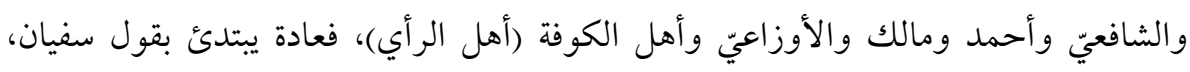

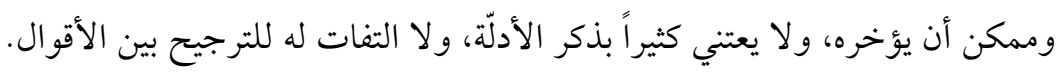

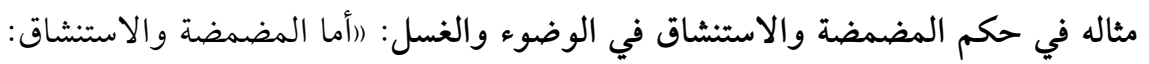

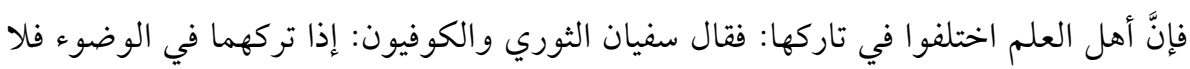

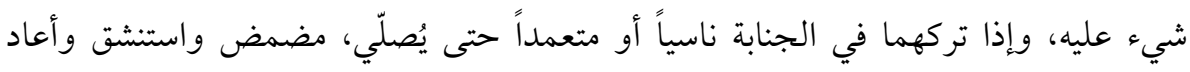

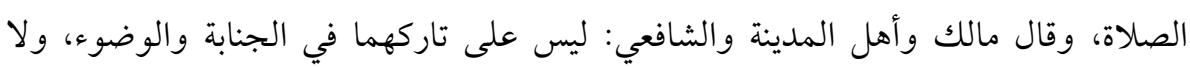

$$
\text { يوجبوها في وضوء و لا غسل. }
$$

وقالت طائفة أخرى من أهل العلم: المضمضة ولان والاستنشاق واجبان في الوضوء والغسل

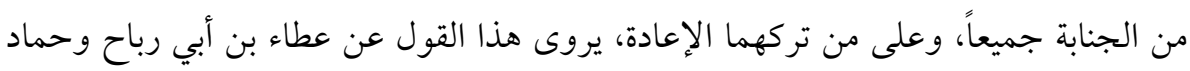

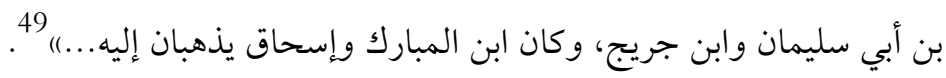

47 يوسف بن قزغلي سبط ابن الجوزي، إيثار الإنصاف في آثار الخلاف، القاهرة: دار السلام، ط1، 1408ه، ص258. 48 محمد بن إسحاق بن النديم، الفهرست، بيروت: دار المعرفة، 1398هـ، ج1، ص299، صالبع، والبدادي، هدية

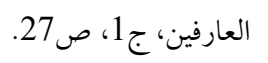

49 محمد بن نصر المروزي، اختلاف الفقهاء، الرياض: أضواء السلف، ط1، 1420هـ/2000م، ج1، ص97- 
2.مختصر اختلاف العلماء: لأبي بكر أحمد بن علي الجصّاص الحنفيّ (ت370هـ)،

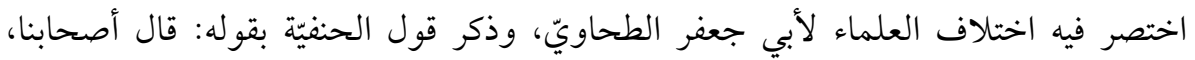

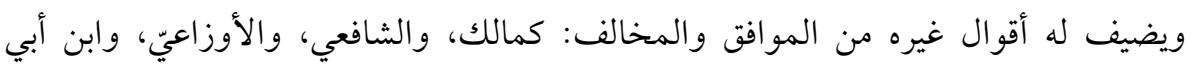

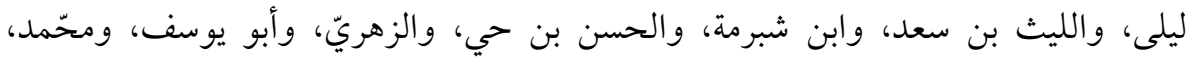

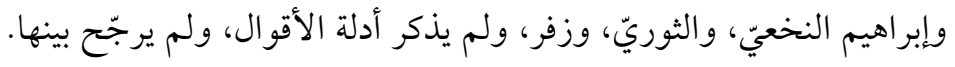

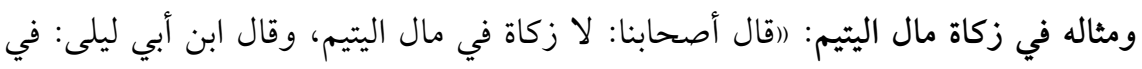

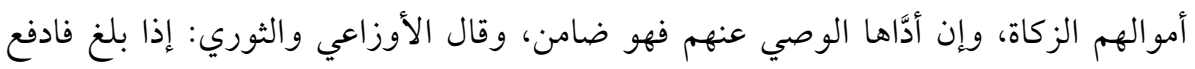

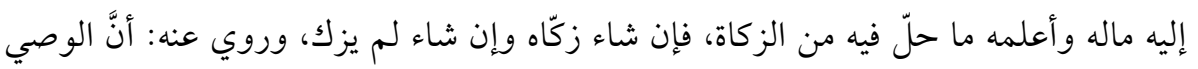

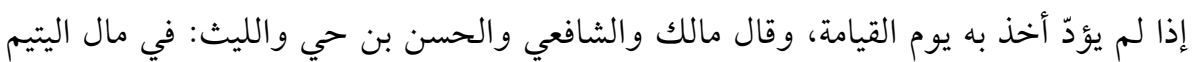

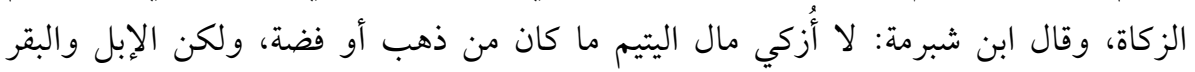
والغنم" (20)

3.حلية العلماء في اختلاف الفقهاء:لمحمد الشاشيّ الشافعيّ (ت507هـ). بيَّن منهجه

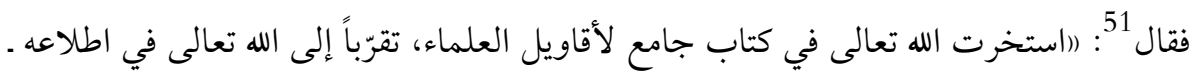

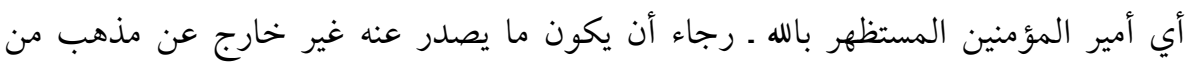

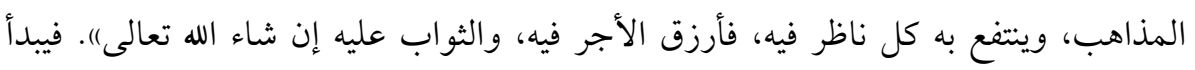

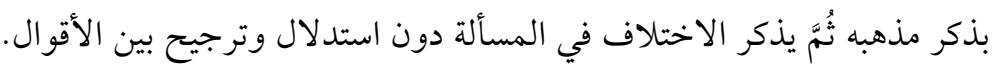

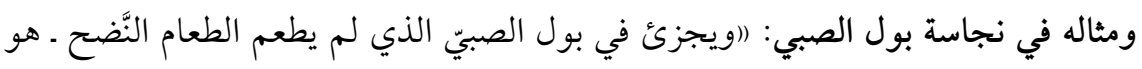

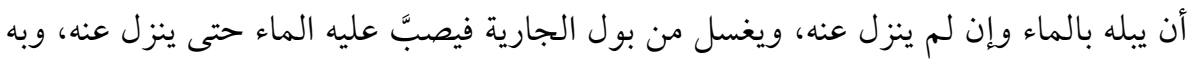

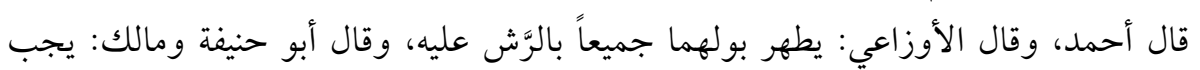

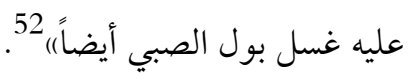

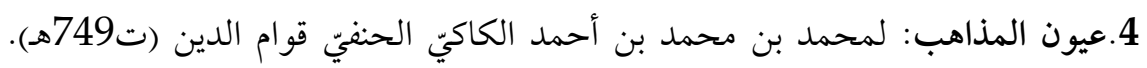

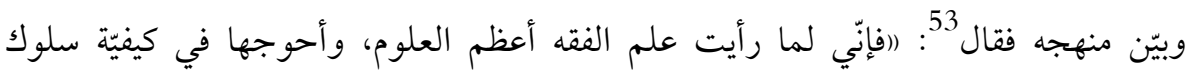

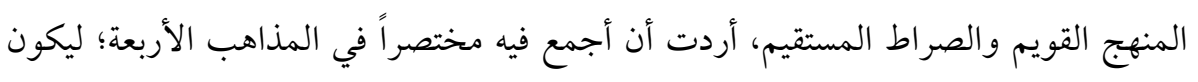

50 أحمد بن محمد بن سلامة الطحاوي، مختصر اختلاف العلماء، بيروت: دار البشائر الإسلامية، ط2،

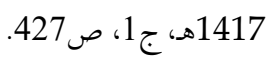

51 محمد بن أحمد الشاشي القفال، حلية العلماء في معرفة مذاهب العلماء الفقهاء، الأردن: مؤسسة الرسالة

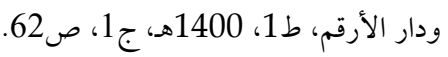

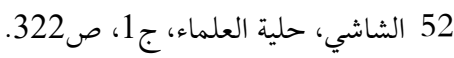

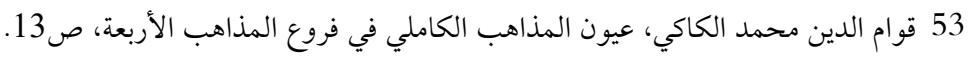


سهل الانقياد وعليه الاعتماد، ترغيباً للطلبة في الحفظ والاجتهاد...). فهو كتاب مختصر في

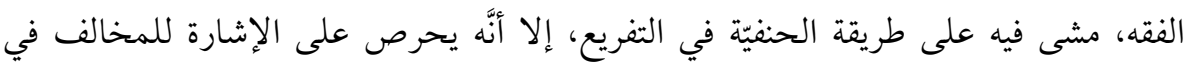

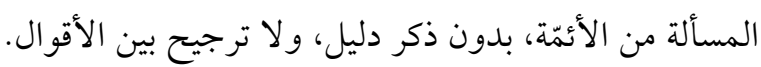

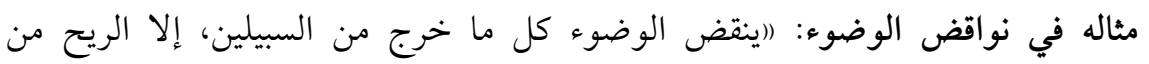

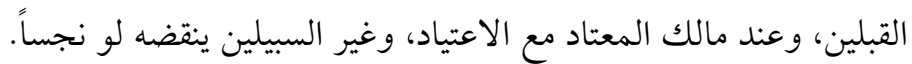

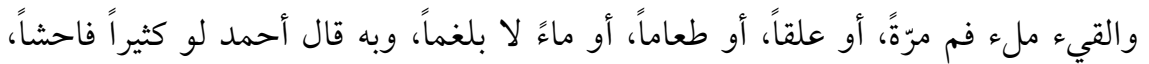

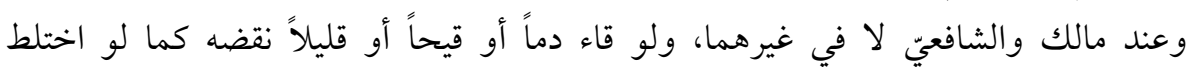
بالبصاق فغلبه أو ساواه) 54

الثالث: ذكر الاتّاق في الباب ثم الاختلاف وعلته بدون ترجيح ولا استدلال نقليّ:

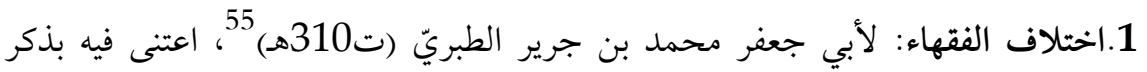

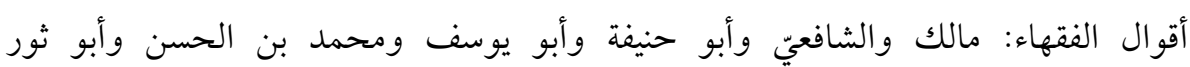

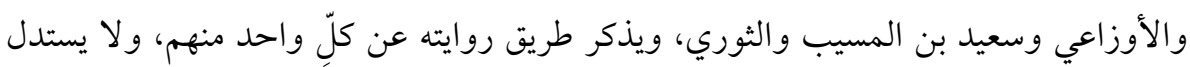

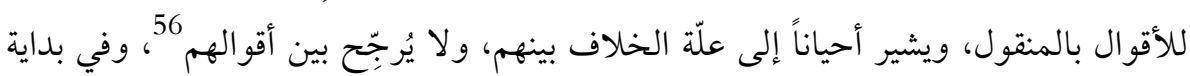

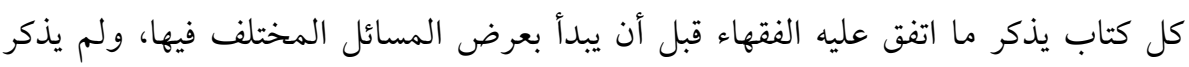

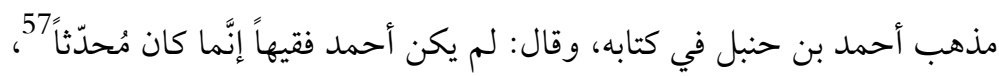

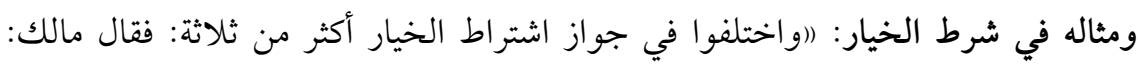

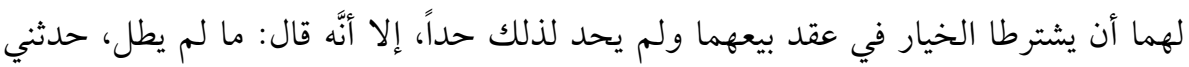

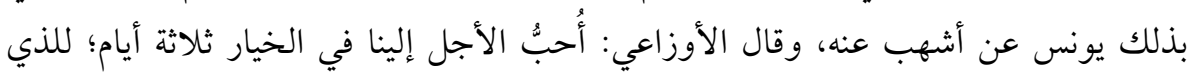

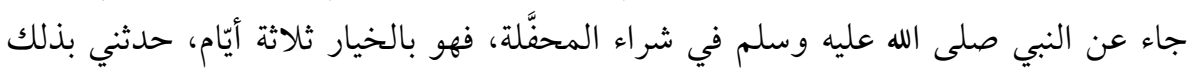

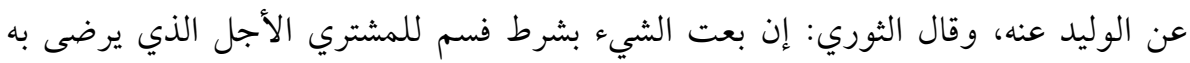

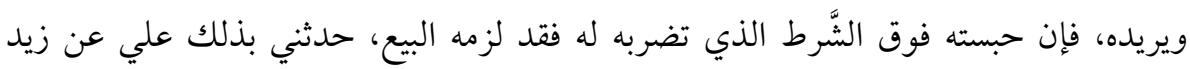

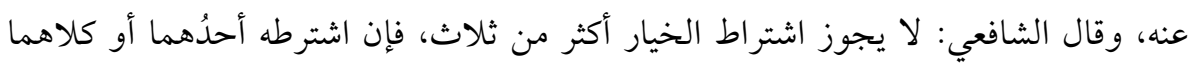

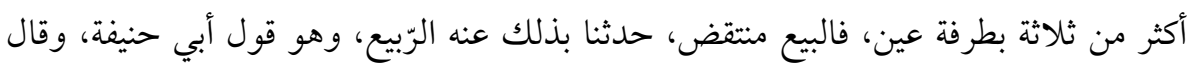

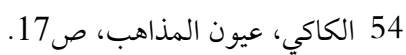

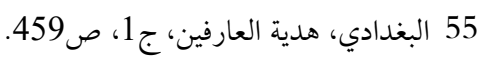

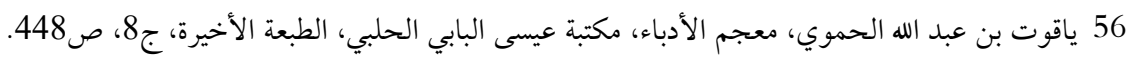

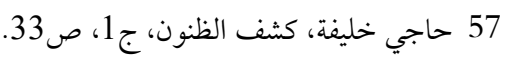


أبو يوسف ومحمد: الخيارُ جائزٌ ما اشترطا إذا كان إلى وقت معلوم، الجوزجانيّ عن محمّد،

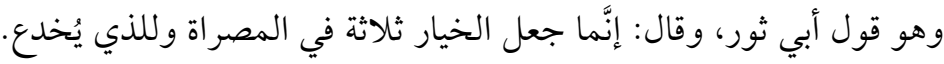

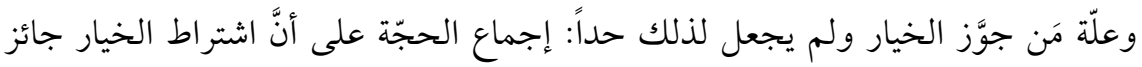

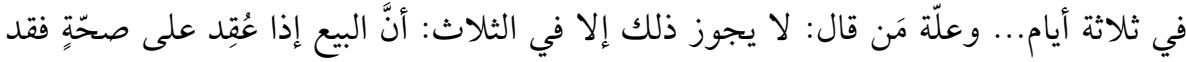

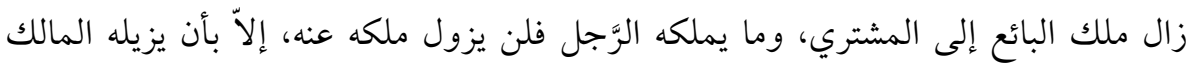

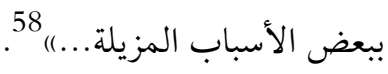

2.اختلاف الفقهاء: لأبي المظفر يحيى ابن هبيرة الوزير (560هـ) 59 فيبدأ بذكر ما اتفق

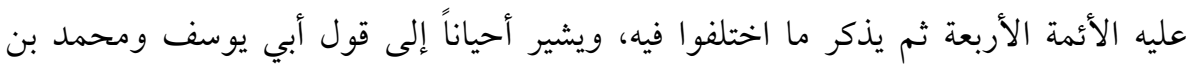

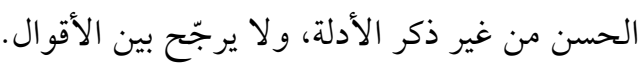

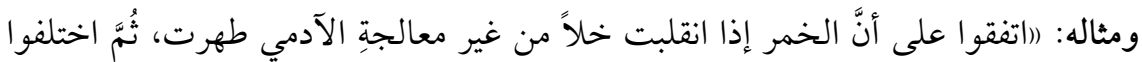

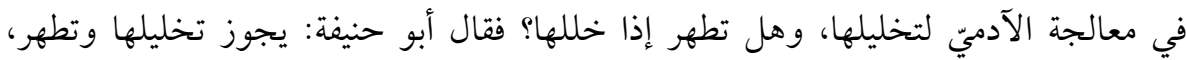

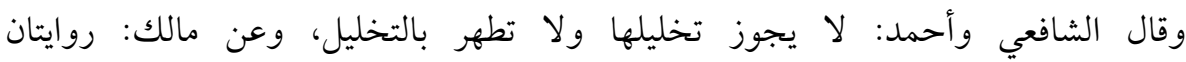
كالمذهبين....). 3.زبدة الأحكام في مذاهب الأيمّة الأربعة الأعلام: لسراج الدين عمر بن إسحاق بن

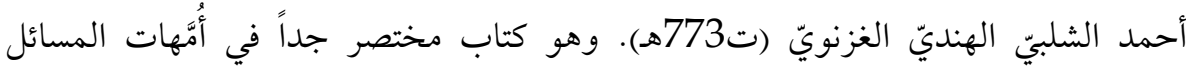

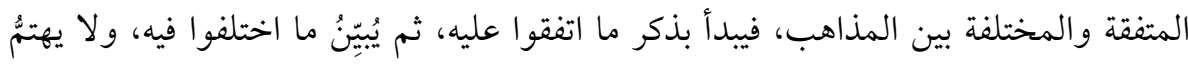

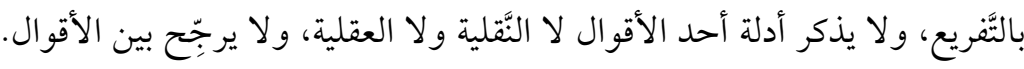

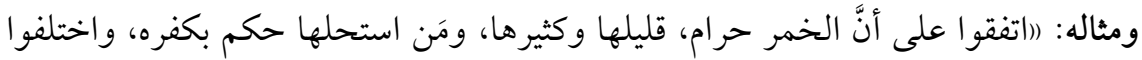

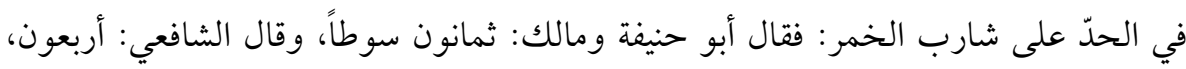
وعن أحمد روايتان: كالمذهبين)" 60

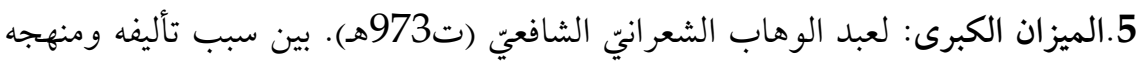

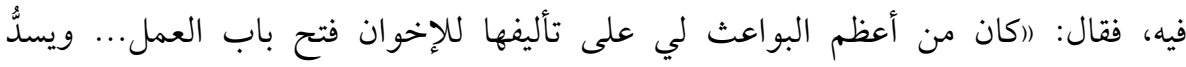

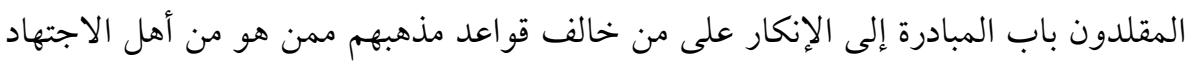

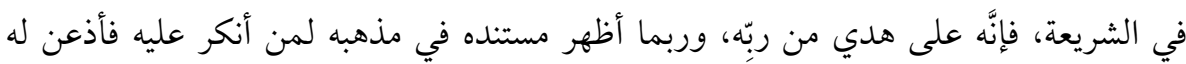

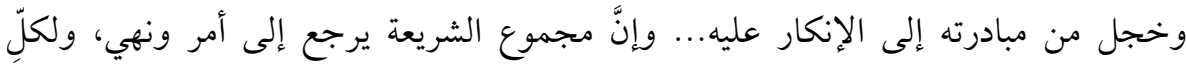

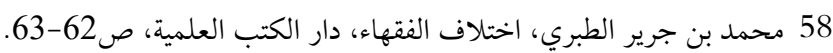

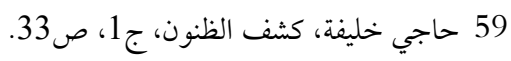
60 عمر بن إسحاق الغزنوي، زبدة الأحكام في مذاهب الأئمة الأربعة الأعلام، مؤسسة الريان، ط1، 2001م، 


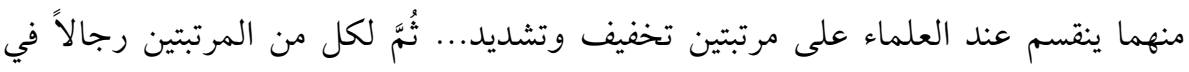

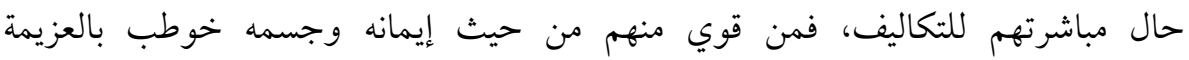

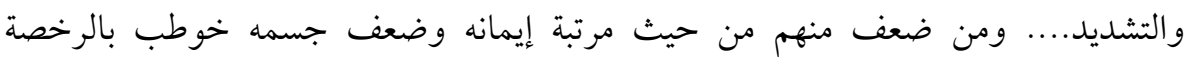

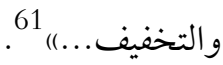

فيهتمُ بذكر مسائل الاتفاق في كل باب، ثُمَّ يبدأ ببيان مسائل الاختلاف، وحمله الخلاف

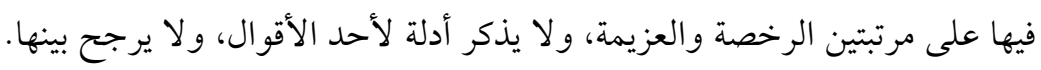

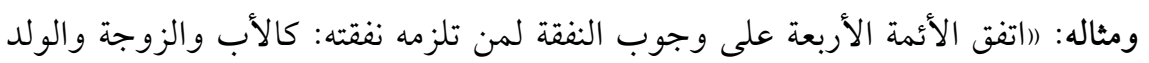

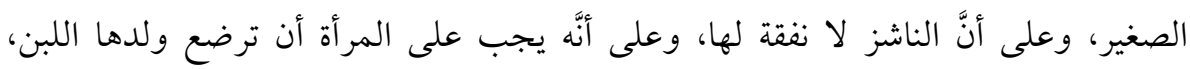

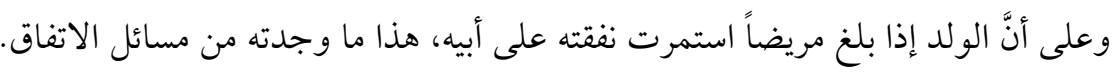

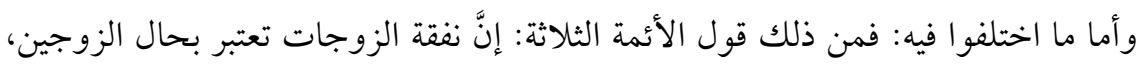

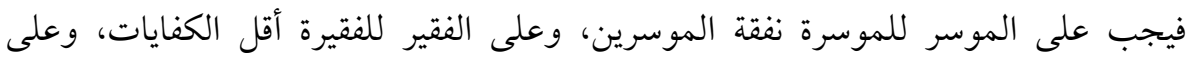

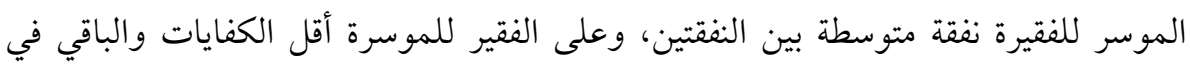

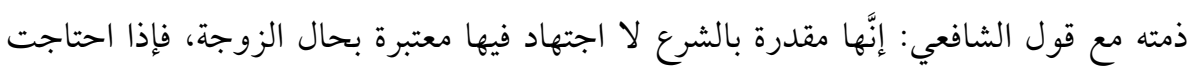

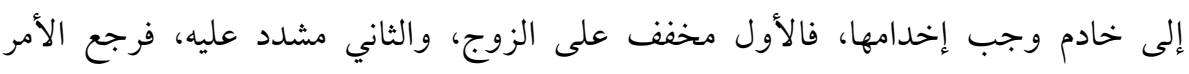

$$
\text { لمرتبتي الميزان)، } 62 .
$$

الرابع: ذكر الأحاديث والاختلاف فيها والترجيح بالحديث مع الاستدلال:

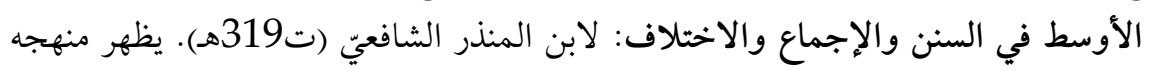

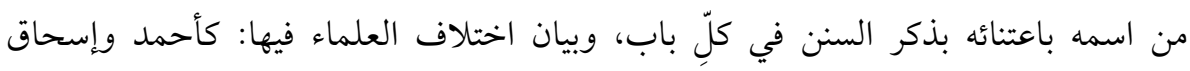

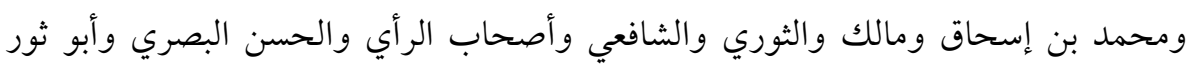

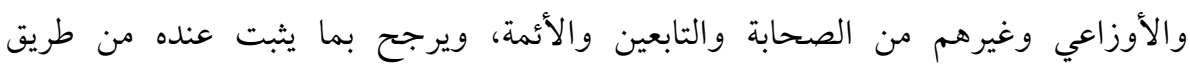

$$
\text { الحديث، ويستفيض في الاستدلال لما رجحهـ. }
$$

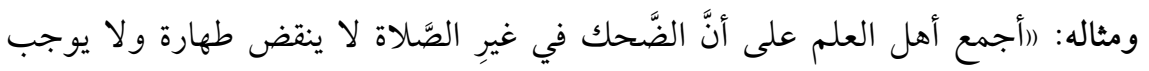

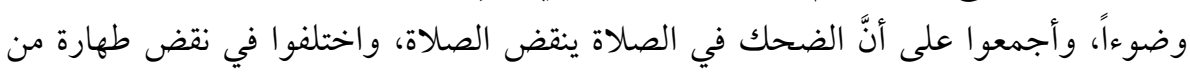

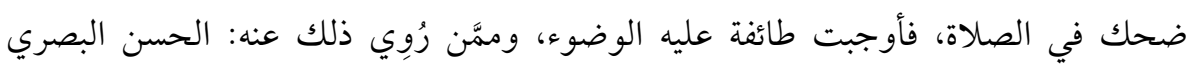

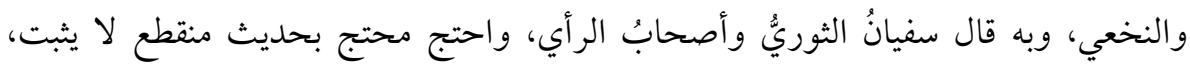

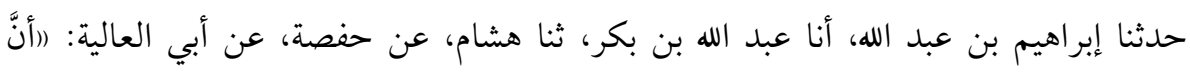

$$
61 \text { الشعبداني، الوهاب بن أحمد الشعراني، الميزان الكبرى، دار العلم للجميع، ط138، ج1، ص4. }
$$


رجلاً ضرير البصر جاء والنبي صلى الله عليه وسلم يُصلّي بالناس فتردَّى في حفرة في

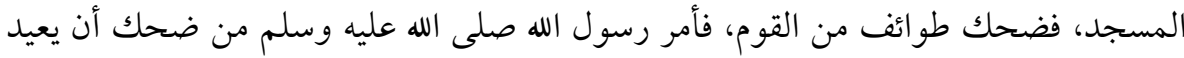

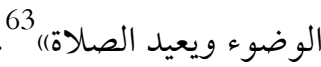

وقالت طائفة: ليس على من ضحك في الصلاة وضوء، روي هذا القول عن جابر بن عبد

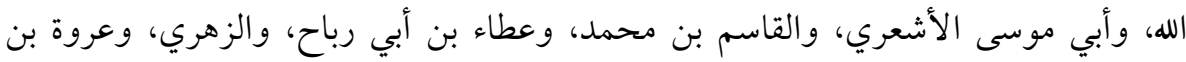

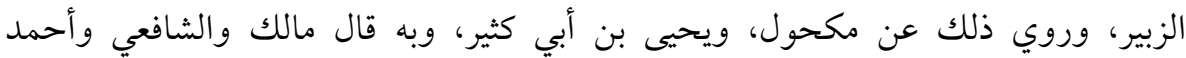

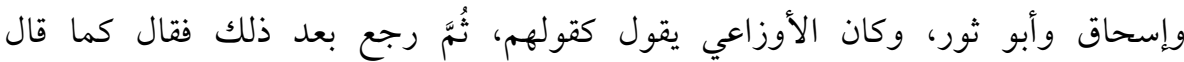
الثوري... (1).

الخامس: ذكر الاختلاف في المذهب وخارجه مع الاستدلال:

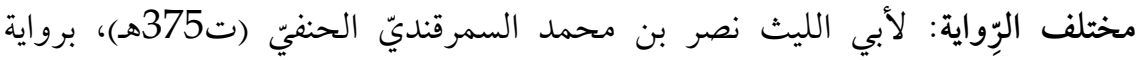

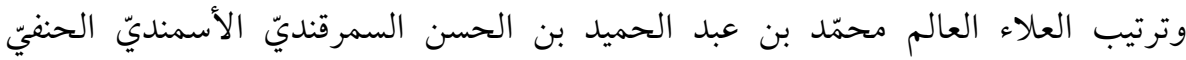

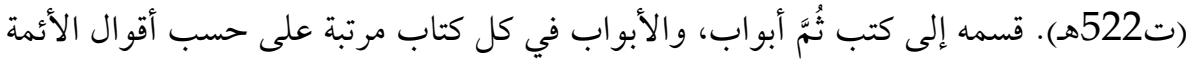

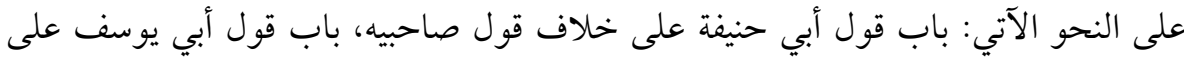

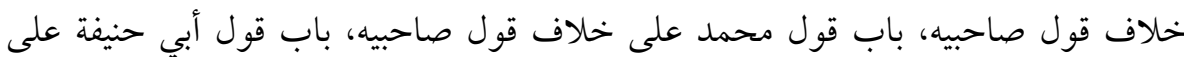

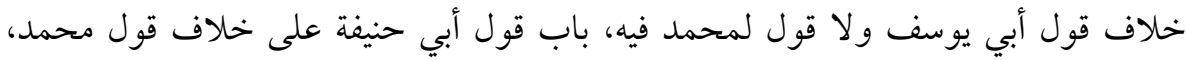

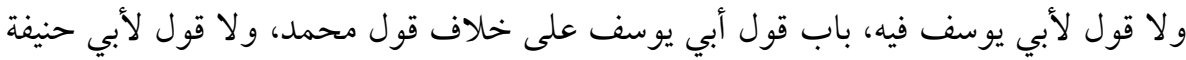

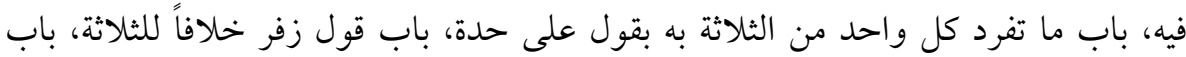

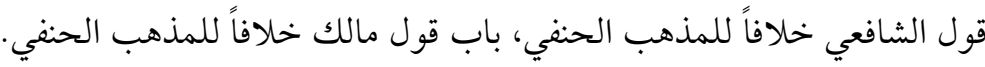

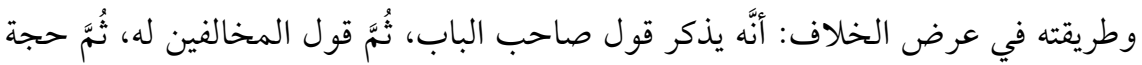

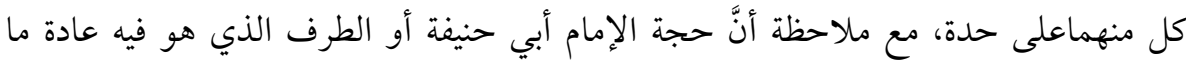

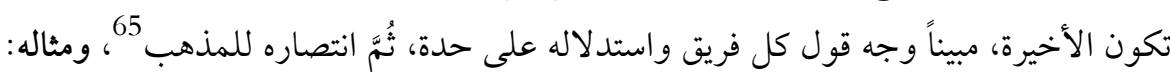

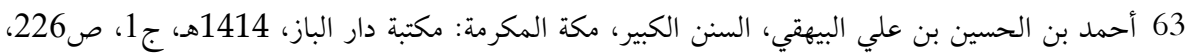

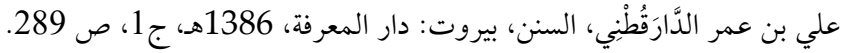

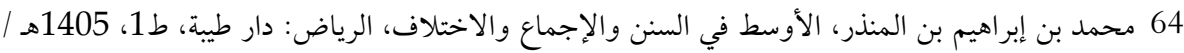

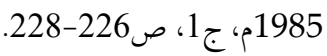
65 عيسى زكي، مقدمة مختلف الرواية، 1987هـ، ج1، ص29-226-30. 
(اقال الشافعي: المشي قدام الجنازة أفضل، وعندنا: خلفها أفضل، له: أنَّأبا بكر وعمر كانا

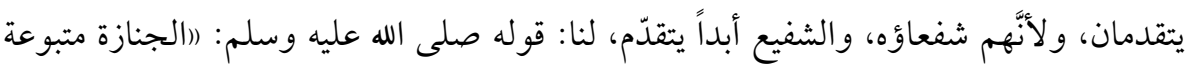

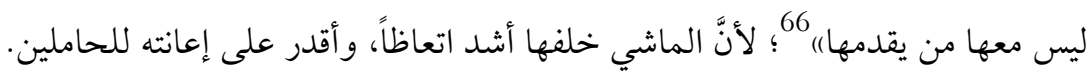

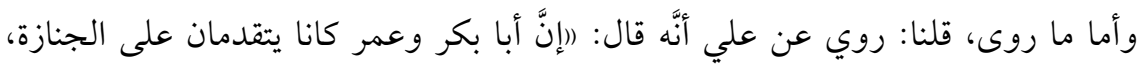

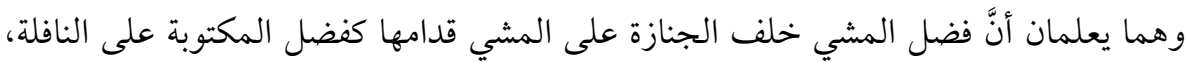

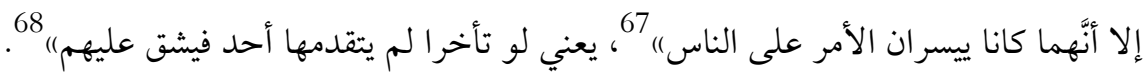
السادس: ذكر الاختلاف وسببه بدون ترجيح:

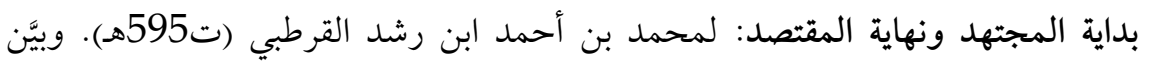

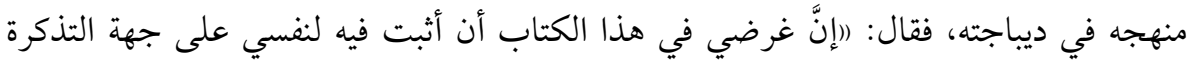

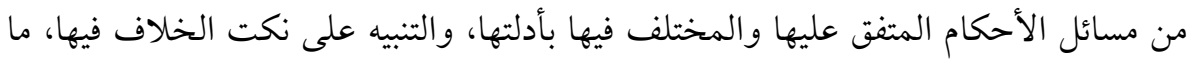

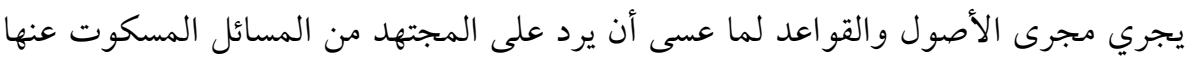

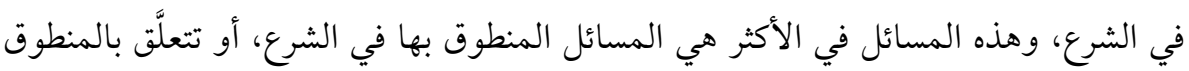

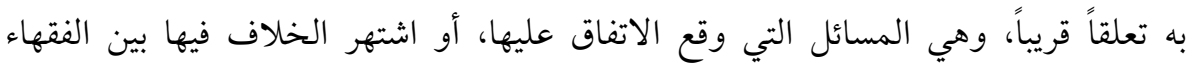
الإسلاميين من لدن الصحابة إلى أن فشا التقليد) .69.

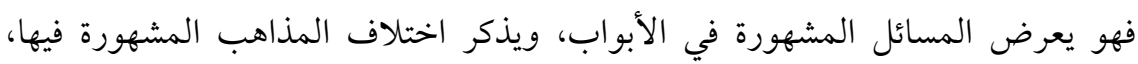
ويشير إلى أدلتهم، ويذكر سبب اختلافهم، بدون عناية بالترجيح بينهم.

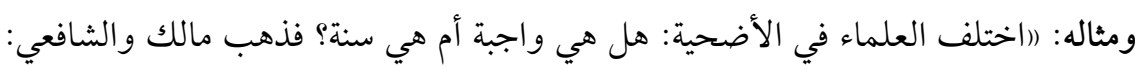

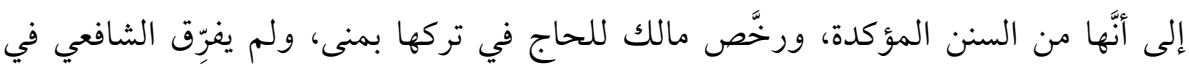

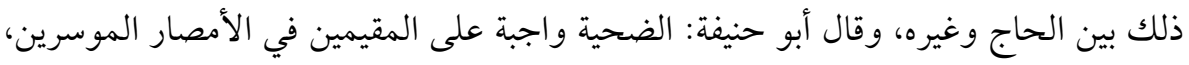

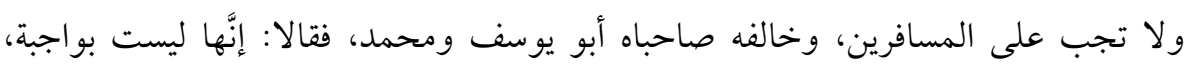
ورُوي عن مالك مثل قول أبي حنيفة.

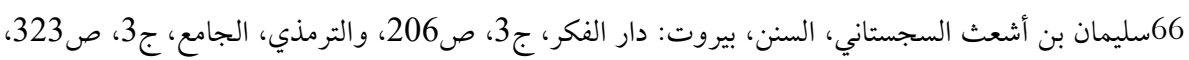

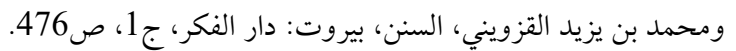

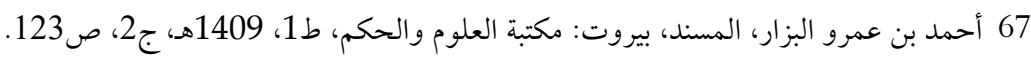

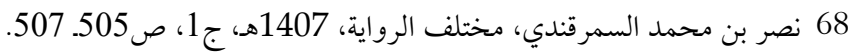

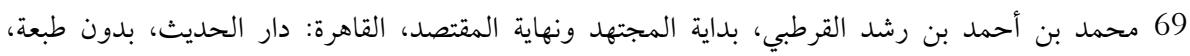

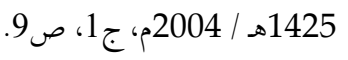


وسبب اختلافهم شيئان: أحدهما: هل فعله في ذلك محمول على الوجوب أو على إحلى

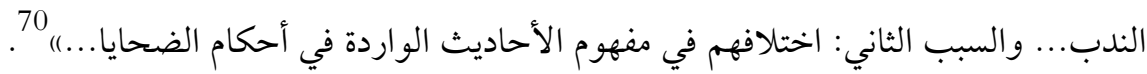

المبحث الثاني: مناهج التأليف في ((علم الخلاف)):

ذكر خلاف الخصم ونقض دليله:

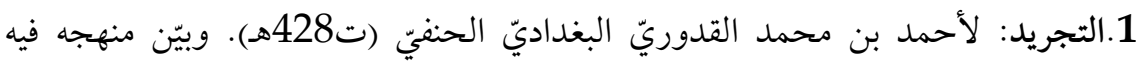
فقال: „رقد أفردنا في هذا الكتاب ما خالف فيه الشافعي بإيجاز الألفاظ، واستيفاء معانيه،

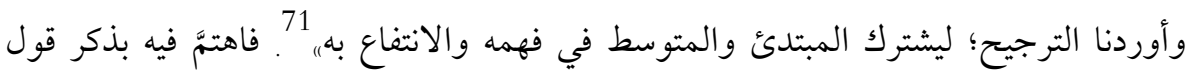

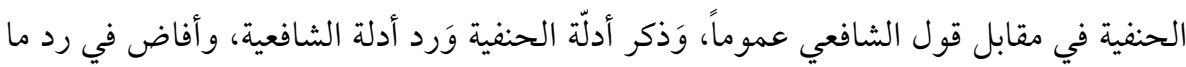

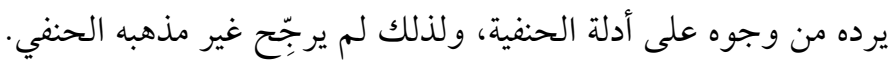

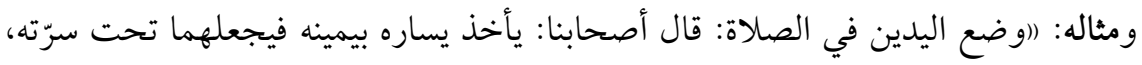

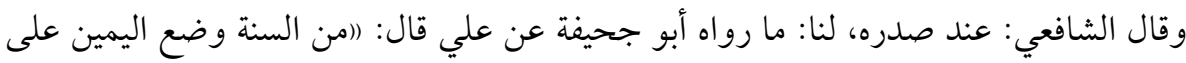
اليسار تحت السرة) 72

احتجوا بحديث وائل بن حجر أنَّ النبي صلى الله عليه وسلم: (اكان يضع اليمين على الى

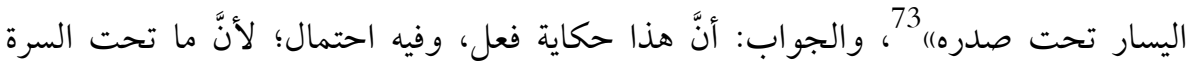

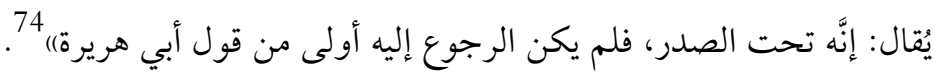

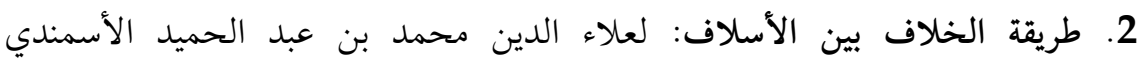

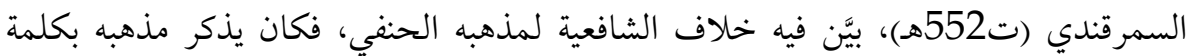

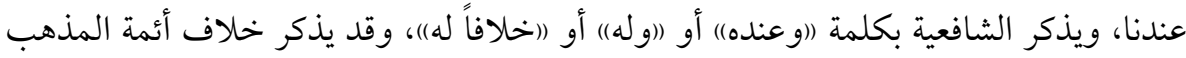

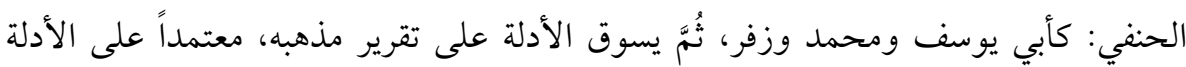

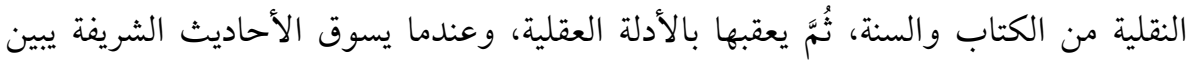

$$
\begin{aligned}
& 70 \text { ابن رشد، بداية المجتهد، ج2، ص192. }
\end{aligned}
$$

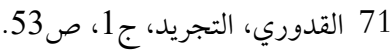

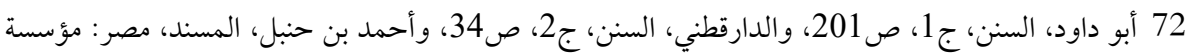

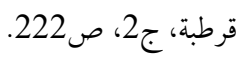

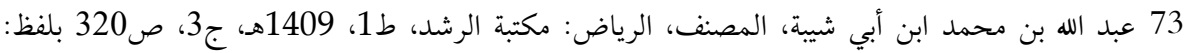

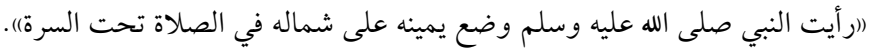

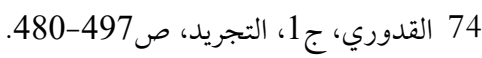


غالباً مخرجها، ثُمَّ يعقبها بالثفسير، ثُمَّ يورد اعتراضات من جهة الخصم ويسلم لهم بذلك ثُمَّم

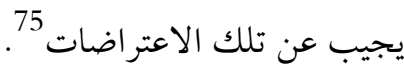

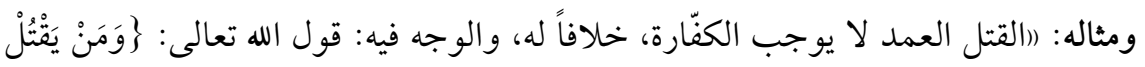

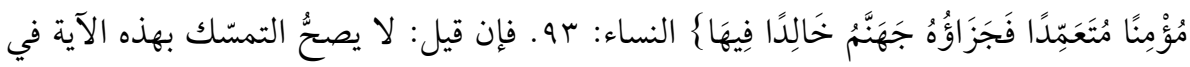

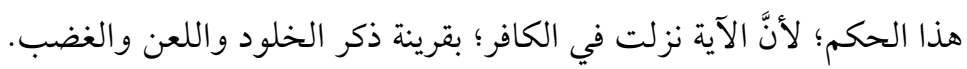

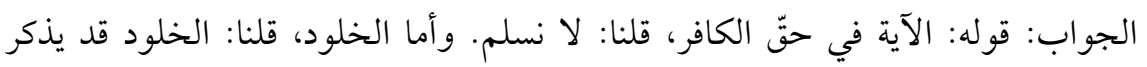

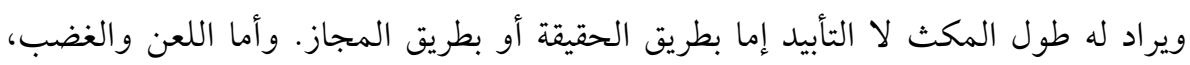
فذاك عبارة عن الإبعاد من الرحمة، وقد يكون ذلك مؤقتاً، فيستحقُه القاتل العامد...1) 76.

المبحث الثالث: مناهج التأليف في ((الفقه المقارن)): وهي أربعة مناهج تفصيلها كالآتي:

الأول: المقارنة بين آقوال المذاهب والاختيار بينها بلا استدلال:

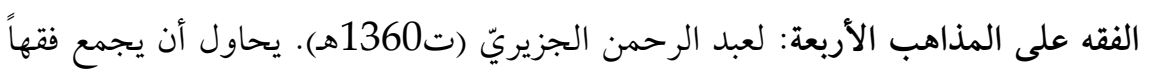

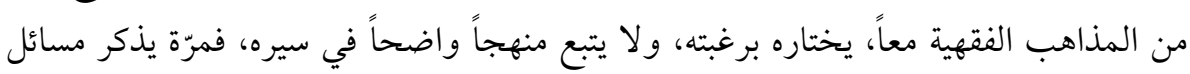

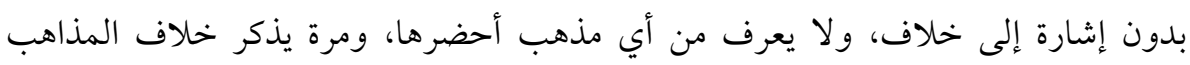

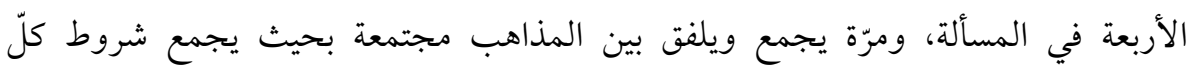

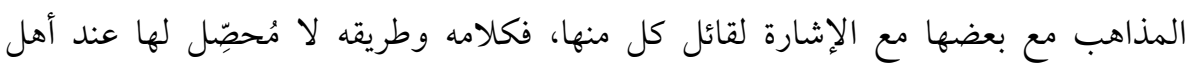
التحصيل. ومثاله: (اشروط المسح على الخف. أحدها: أن يكون الخفُّ ساتراً للقدم مع الكعبين.

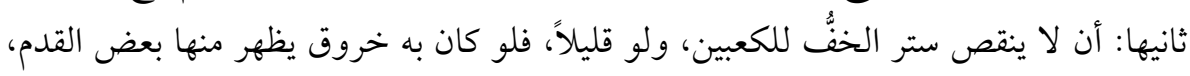

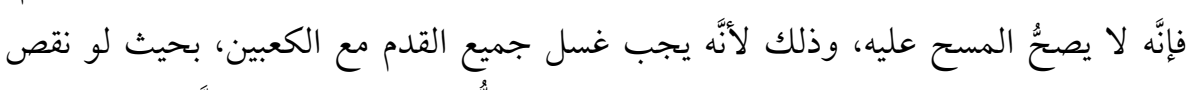

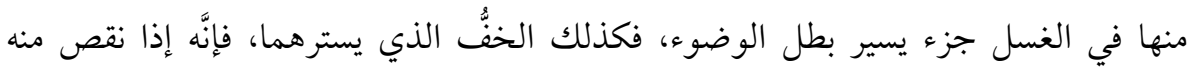
شيء، فلا يقوم مقام القدم، وهذا رأي الحنابلة والشافعية.

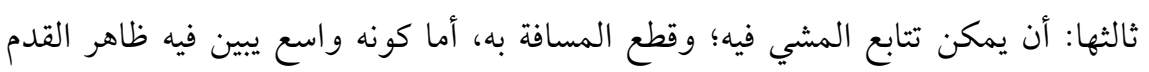

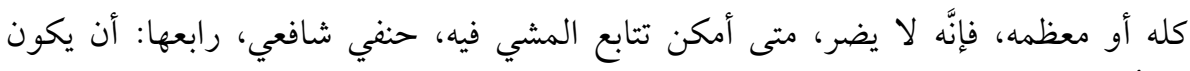

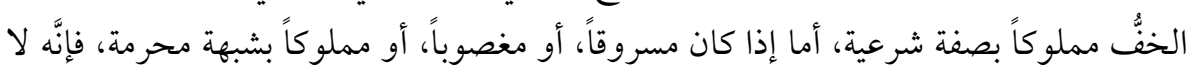

$$
75 \text { علي معوض، مقدمة طريقة الخلاف، ص29. }
$$

76 محمد بن عبد الحميد الأسمندي، طريقة الخلاف بين الأسلاف، بيروت: صافئ دار الكتب العلمية، ط1، 1992م، 
يصح المسح عليه، وهذا رأي الحنابلة، والمالكية، خامسها: أن يكون طاهراً: فلو لبس خُفِّاً

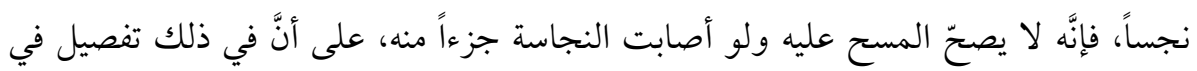

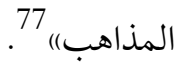

الثاني: المقارنة بين أقوال الفقهاء بدون ترجيح ولا استدلال:

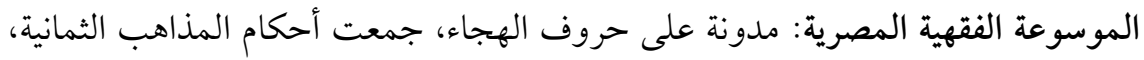

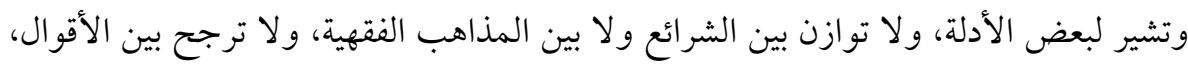

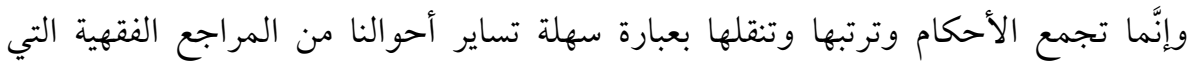

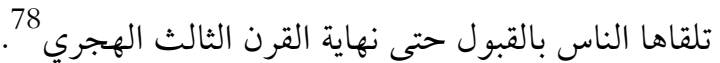
ومثالها: (الأب والقضاء لولده أو عليه وبالعكس:

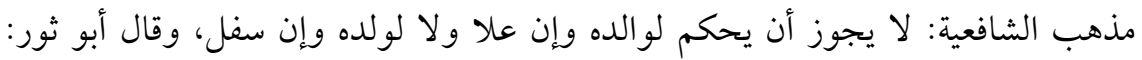

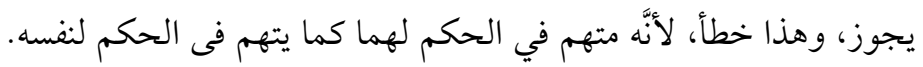

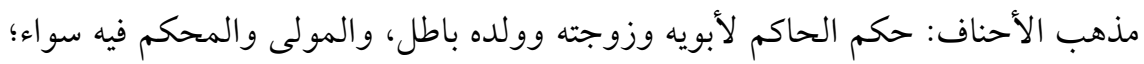

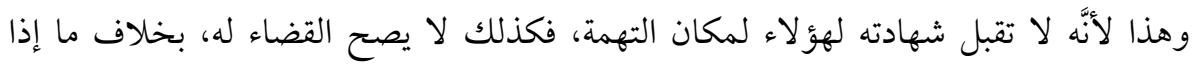

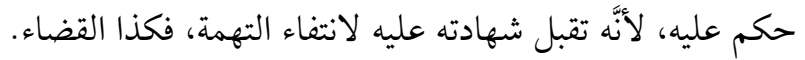

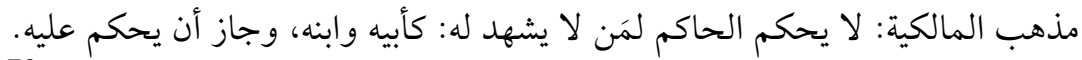

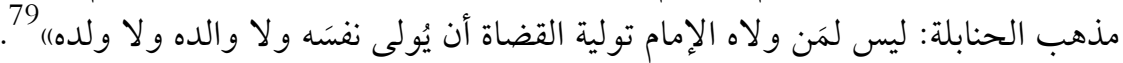

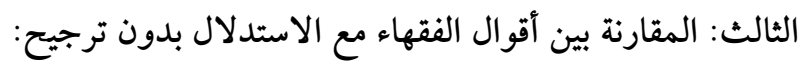

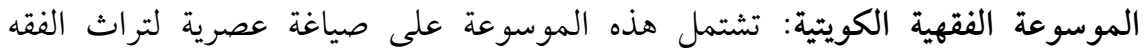

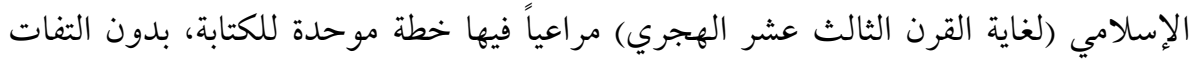

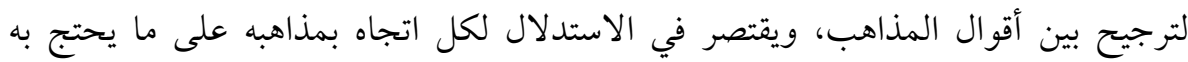
أصحابه من أدلة المنقول والمعقول إذا جاء بطريق الدلالة المباشرة.

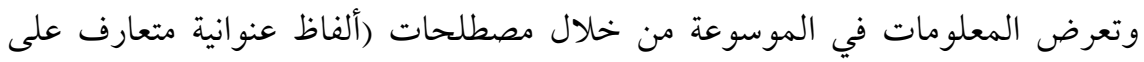

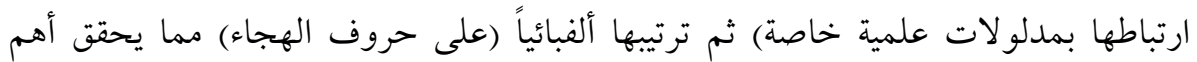

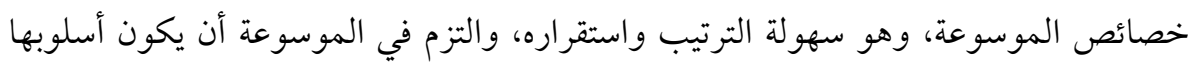

77 عبد الرحمن الجزيري، الفقه على المذاهب الأربعة، القاهرة: دار الفجر، ط1، 2000م، ج1، ص127-

78 المجلس الأعلى للشؤون الإسلامية، موسوعة الفقه الإسلامي المصرية، القاهرة، 1386هـ، ج1، ص259. (الموسوعة المصرية، ج1، صل152. 
واضحاً، وهذا غالباً ما يتطلب التصرف في العبارات المقتبسة من المراجع الفقهية؛ لإزالة

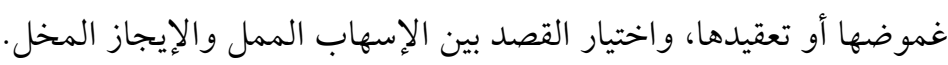

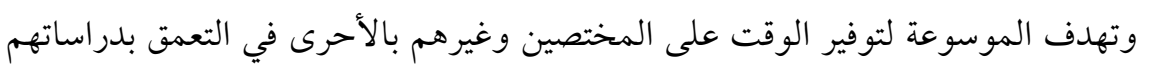

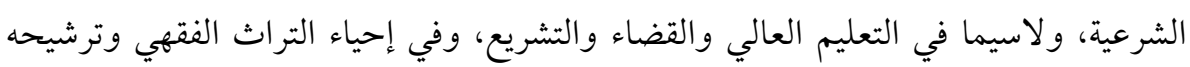

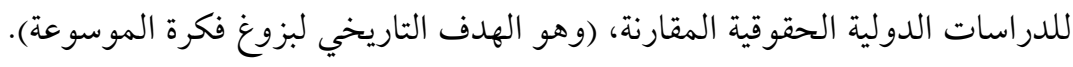

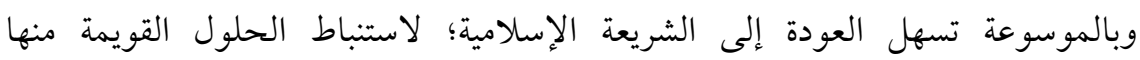

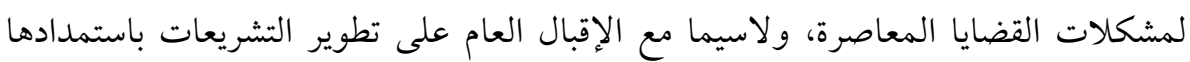

$$
\text { من الشريعة } 80 .
$$

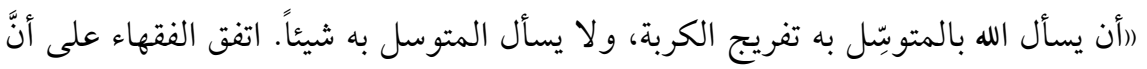

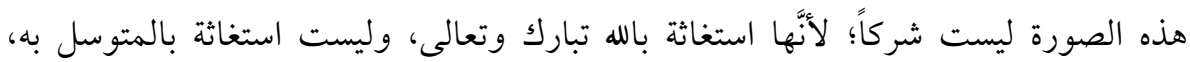

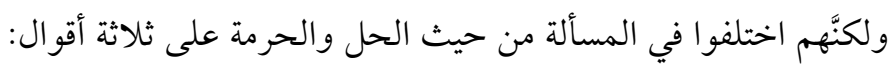

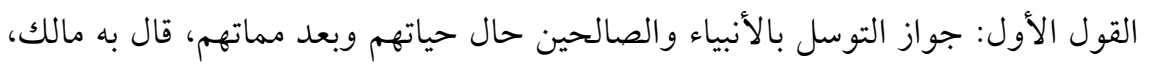

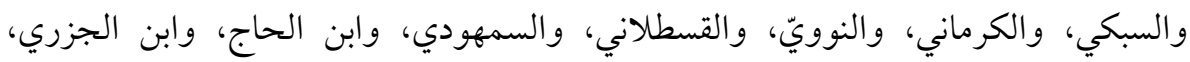

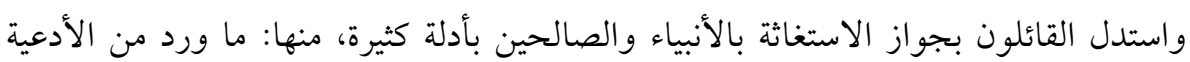

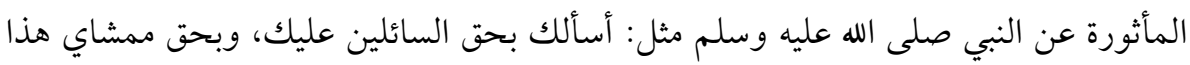

القول الثاني: أجاز العز بن عبد السلام وبعض العلماء الاستغاثة باله متوسلاً بالنبي صلى الهى

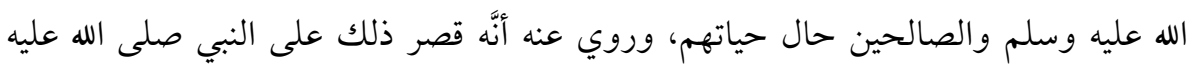

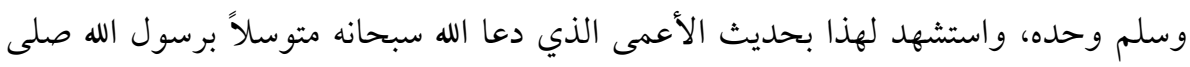

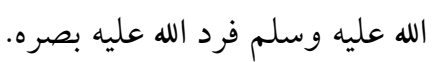

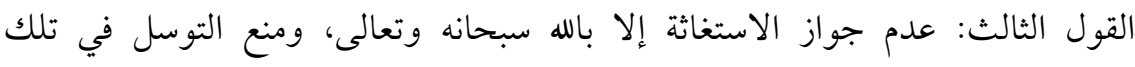

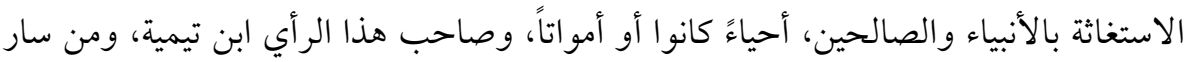

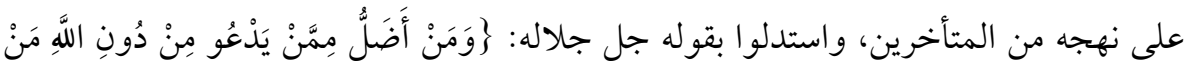

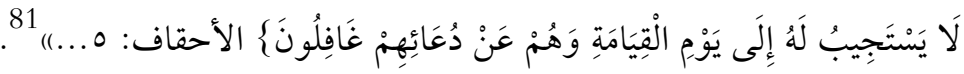


الرابع: المقارنة بين أقوال الفقهاء والإشارة لأدلتهم والترجيح بينها بالحديث:

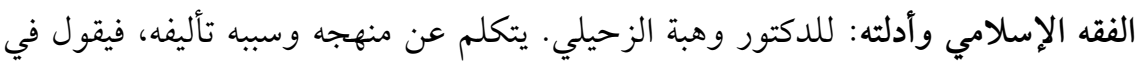

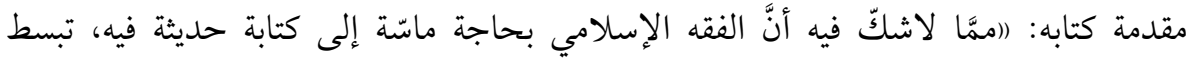

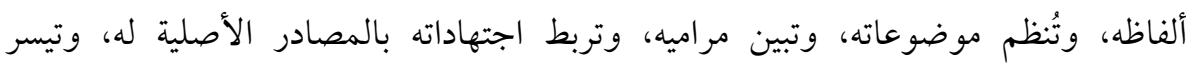

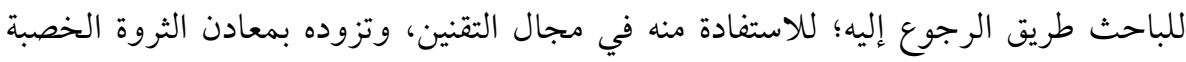

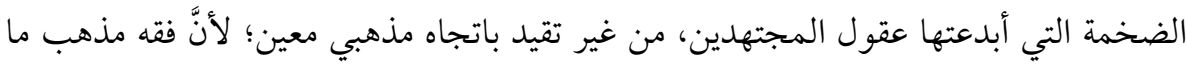
لا يمثل فقه الشريعة كله. وهو ليس كتاباً مذهبياً محدوداً، وإنَّما هو فقه مقارن بين المذاهب الأربعة (الحنفية

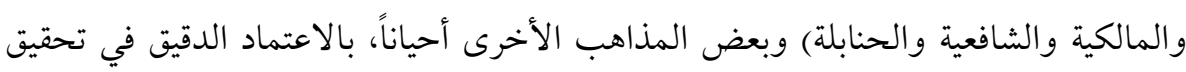

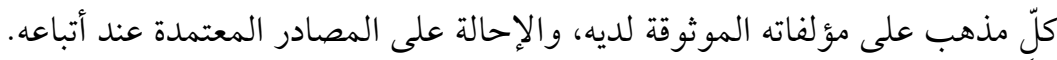

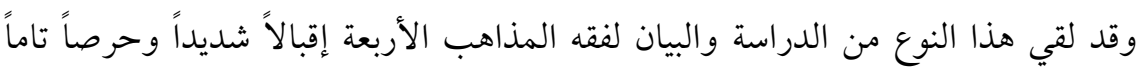
على المطالعة والاستفادة، وهو يتفق مع الاتجاه العالمي للدراسة المقارنة، ويسهم في البعد المدال

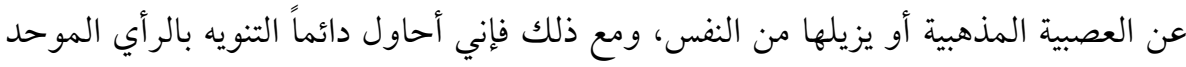

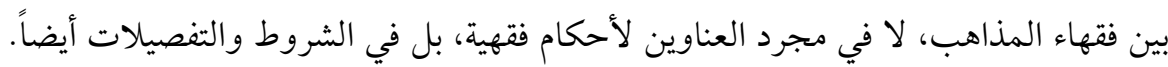

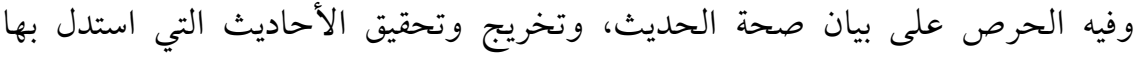

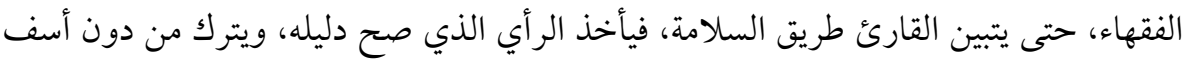

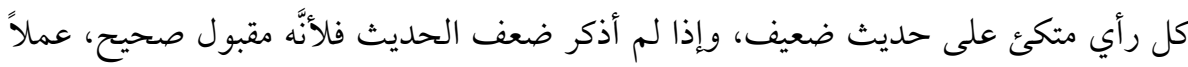

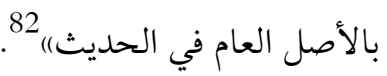

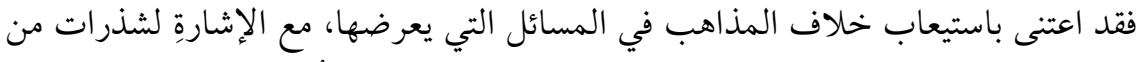

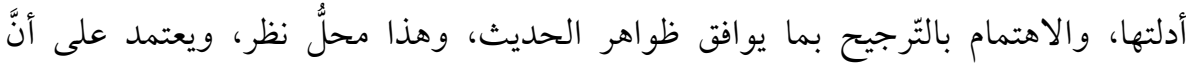

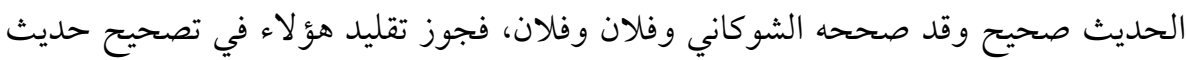

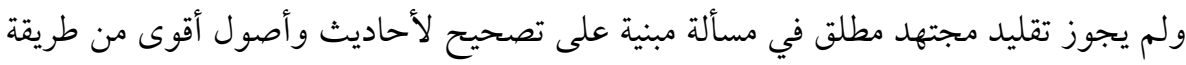
المتأخرين في التصحيح.

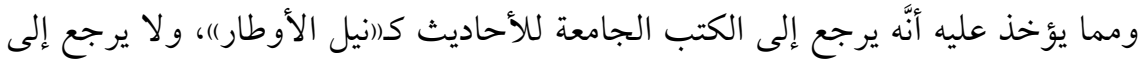

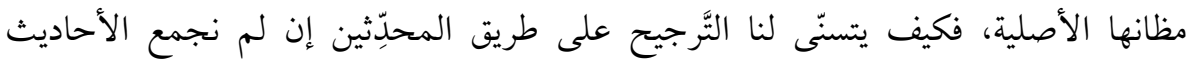

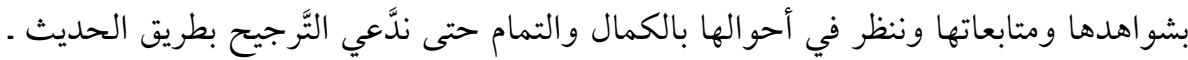
إن سُلِّمت هذه الطريق أصلاً

82 وهبة الزحيلي، الفقه الإسلامي وأدلته، دار الفكر، ط4، ج1، ص20. 
ومثاله: (اقلة الماء وكثرته: اختلف الفقهاء في حدِّ القلّة والكثرة: فالكثرةُ عند أبي حنيفة:

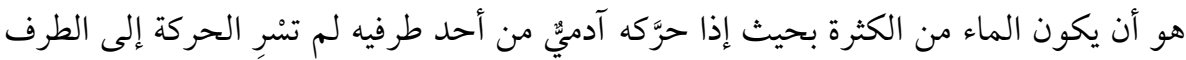

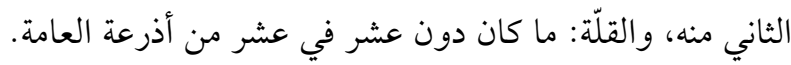

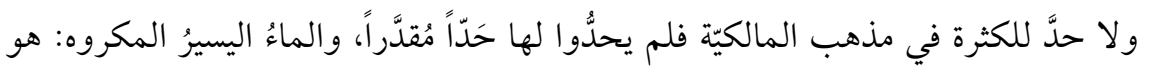

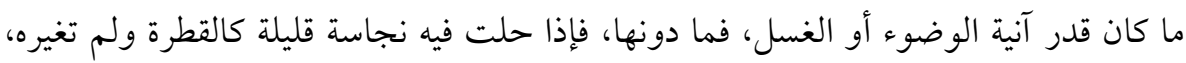

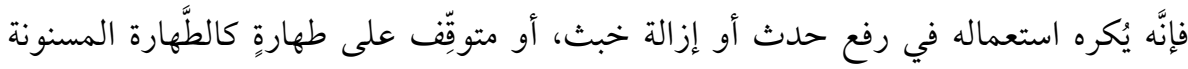
والمستحبّة، ولا كراهة في استعماله في العادات.

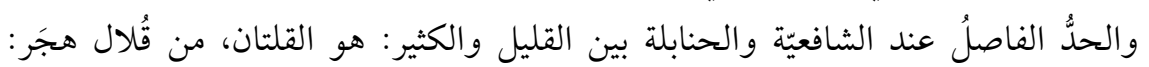

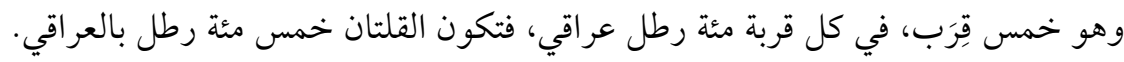

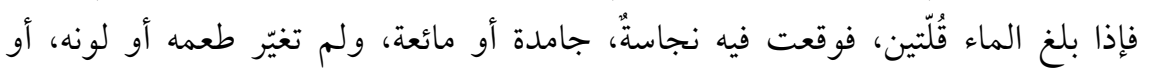

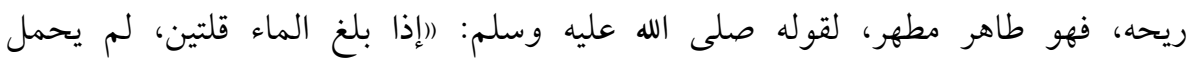

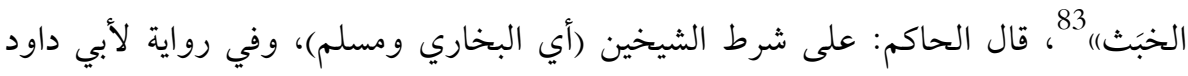

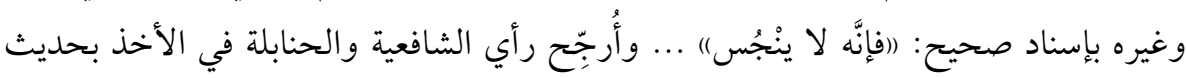

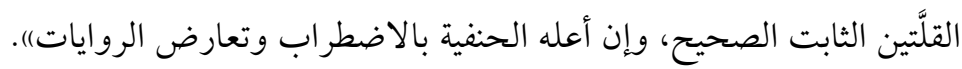

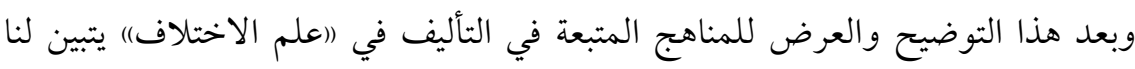
بكل وضوح أنَّ غالبية الكتب التي ألّفت في هذا العرضج العلم كان مؤلفوها متمذهبين ملتزمين

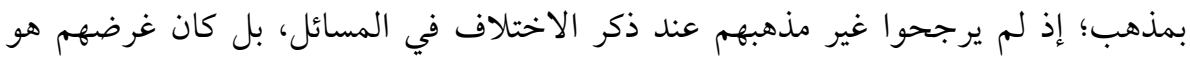

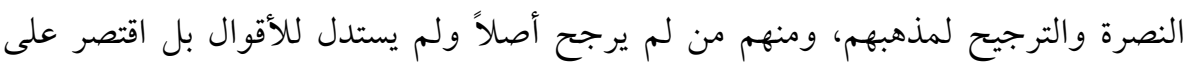
ذكر الاختلاف حتى يسهل على الطلبة معرفة الاختلاف وحفظ المسائل.

\section{والخاتمة:}

وفي ختام هذا البحث نخلص إلى هذه النتائج التي حصلت عليها في النقاط الآتية:

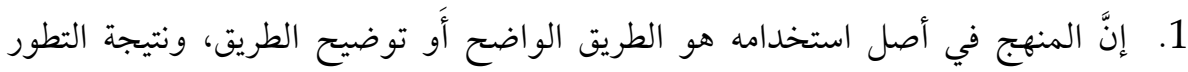

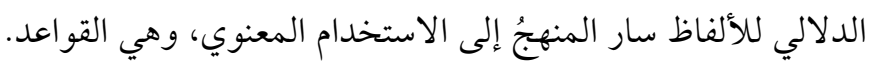

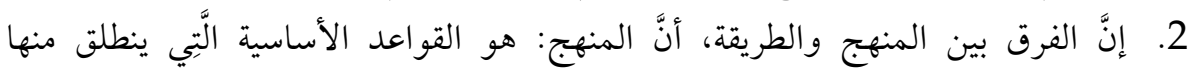

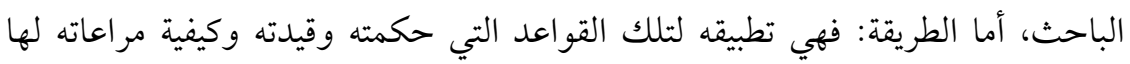
والتزامه بها.

(83 الدارقطني، السنن، ج1، ص18، وابن ماجه، السنن، ج1، ص172. 
3. إنَّ علم الخلاف: هو علم يبحث فيه أقوال الفقهاء قصداً، سواء كانت بأدلتها ونقض قول

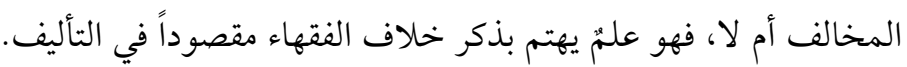

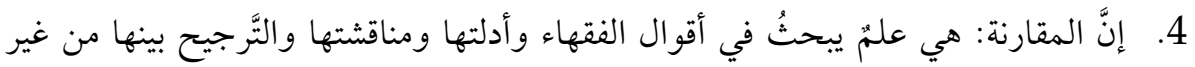

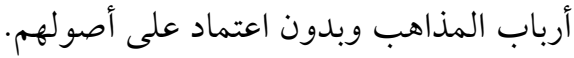

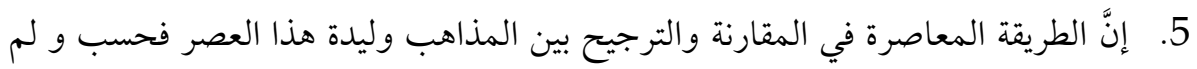
تعرف عند من سبق، وإنَّما ظهرت نتيجة الأفكار الاستعمارية المستوردة، وأول ومَ مَن تناول

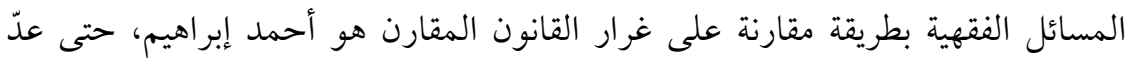
مجدد الفقه الإسلامي. 6. إنَّ (اعلم الاختلاف) الذي سار عليه علماؤنا منذ بدء تدوين فقه المذاهب الإسلامية لا

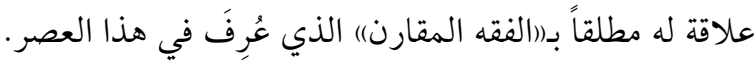

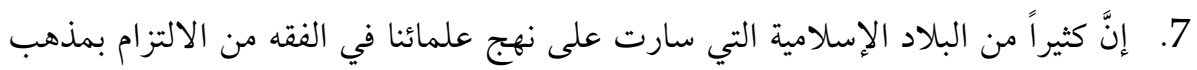

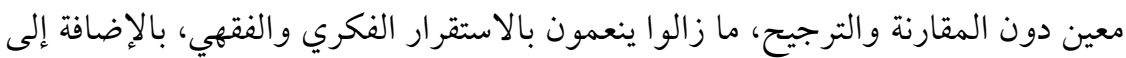

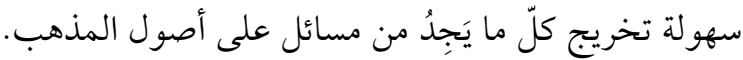

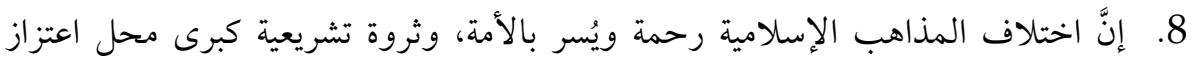

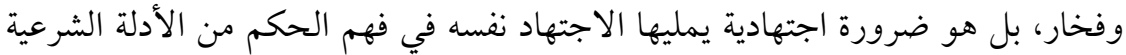
مباشرة. 9. إنَّ ما وصلنا من آثار في فضل (اعلم الاختلاف) والثناء على دارسيه، لا يفهم منه

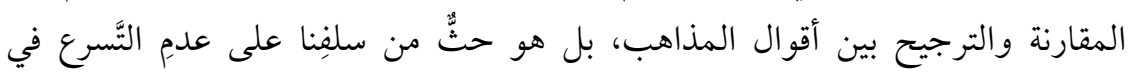

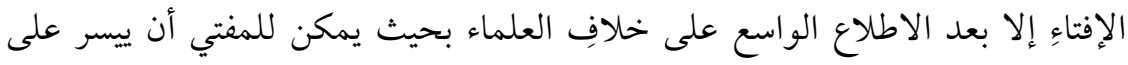
المسلمين. 10. إنَّ الكتب المؤلفة في (فقه الاختلاف)) لا تُعدُّ ولا تُحصى، اتبع في تأليفها تسعة مناهج،

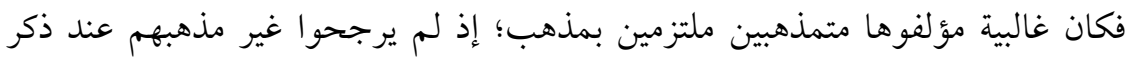

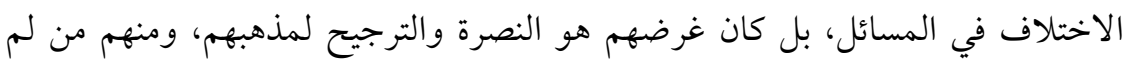

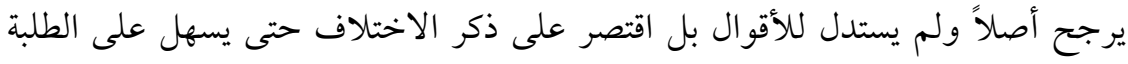

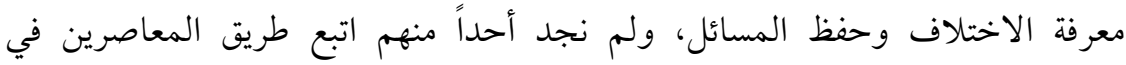
المقارنة والترجيح بين المذاهب. 11. ظهور آثار سلبية كثيرة لشيوع فكرة الفقه المقارن المعاصرة بدل فكرة فقه الاختلاف

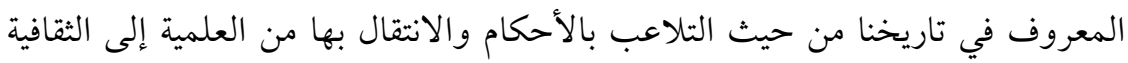


وعدم الاستفادة من التَّفريع والتَّصيل في المذاهب والتَّرجيح بطريقِة غير معتمدة

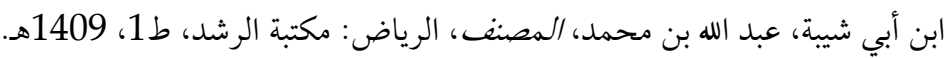

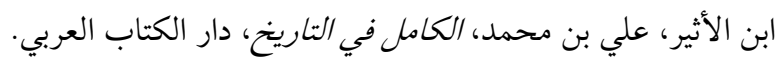

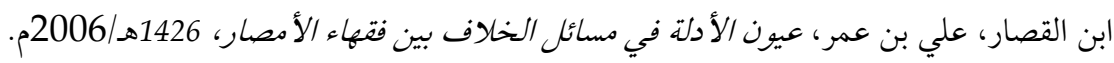

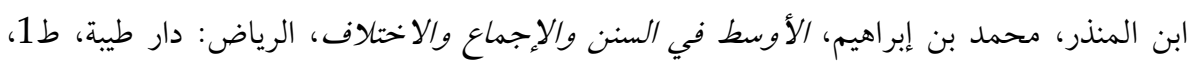

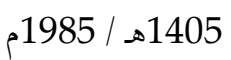

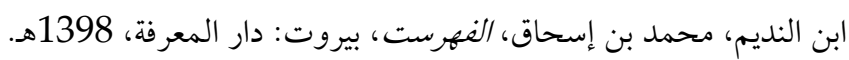

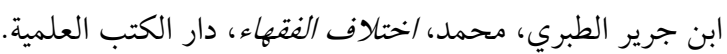

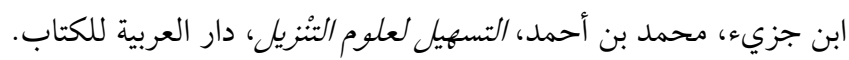

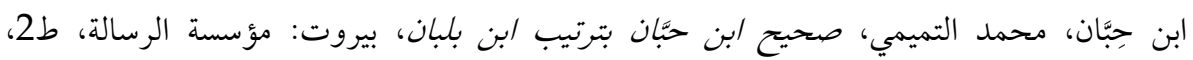
1414هـ

$$
\text { ابن حنبل، أحمد، المسند، مؤسسة قرطبة، مصر. }
$$

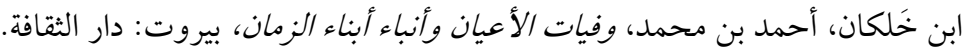

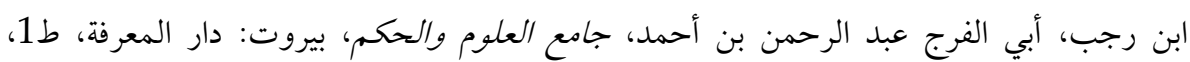
1408هـ

ابن رشد القرطبي، محمد بن أحمد، بداية المجتهل ونهاية المقتصد، القاهرة: دار الحديث، بدون

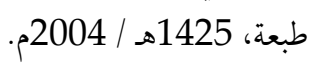

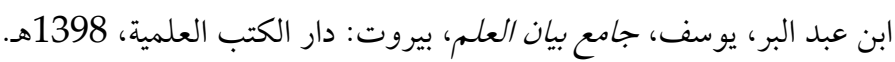

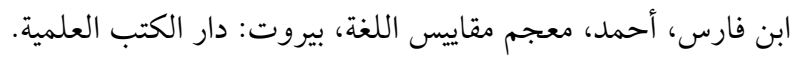

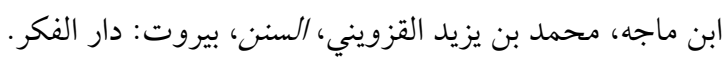

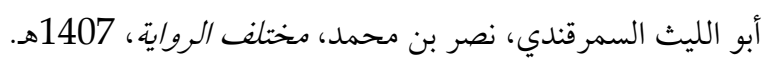

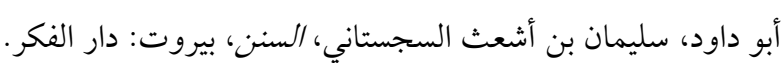

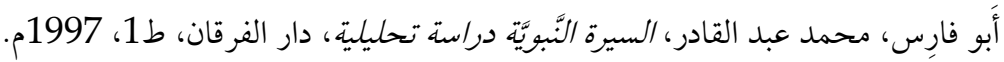

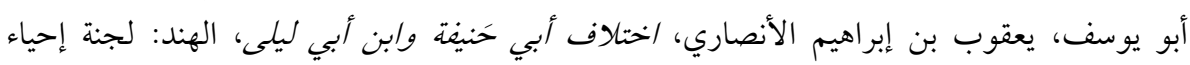

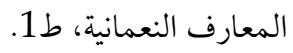

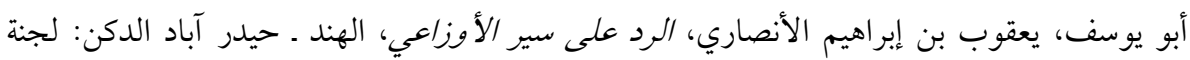

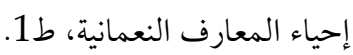

الأسمندي، محمد بن عبد الحميد، طريقة الخلاف بين الأسلاف، بيروت: دار الكتب العلمية، ط1، 
الإسنوي، عبد الرحيم بن الحسين، نهاية السول في شرح منهاج الأصول، بيروت: دار الكتب العلمية، ط1، 1984م. الأصبحي، مالك بن أنس، الموطأ، مصر : دار إحياء التراث العربي.

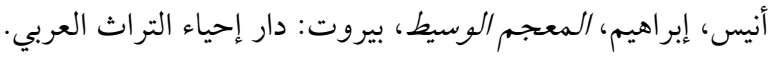

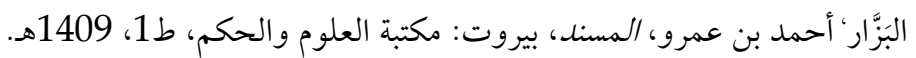

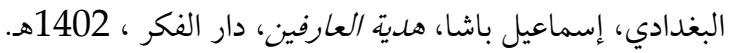

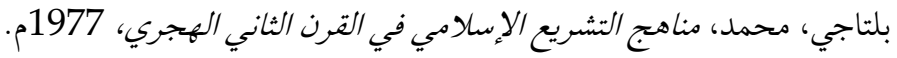

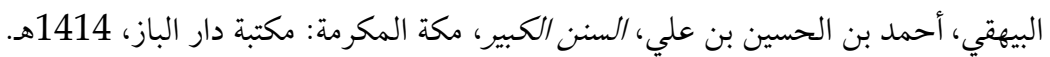

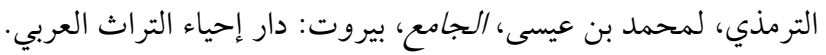

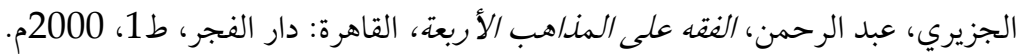
جماعة من العلماء، الموسوعة الفتهية الكويتية، وزارة الأوقاف الكويتية.

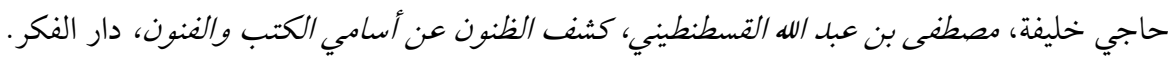

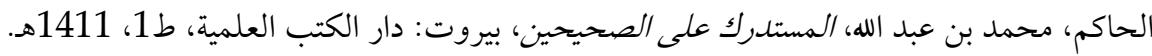

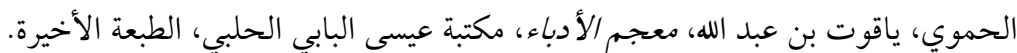

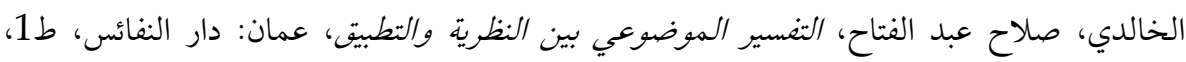
1997م

الخطيب البغدادي، أحمد بن علي، تاريخ بغداد، بيروت: دار الكتب العلمية.

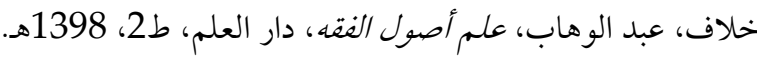

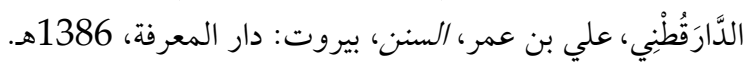

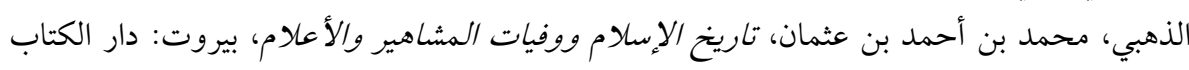

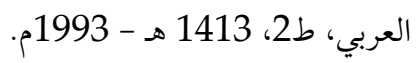

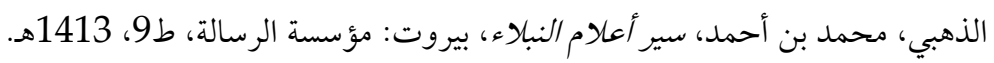

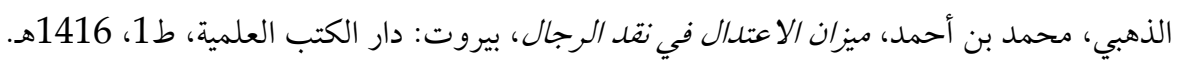

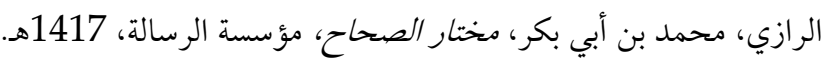

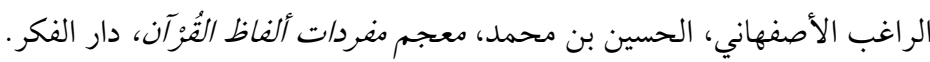

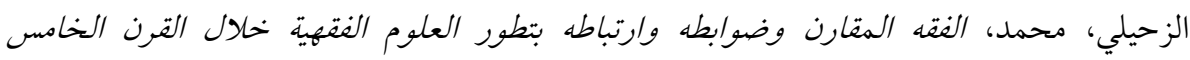
الهجري، http://dc380.4shared.com

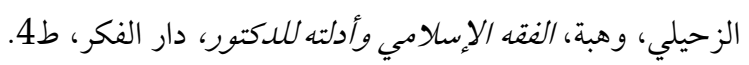

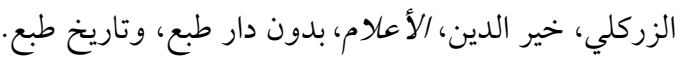

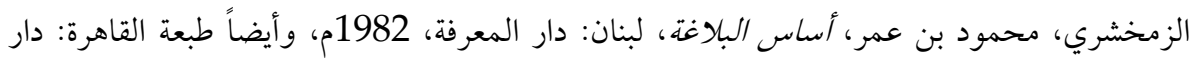

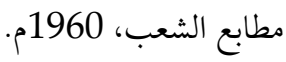


سبط ابن الجوزي، يوسف بن قزغلي، إيثار الإنصاف في آثار الخلاف، القاهرة: دار السلام، ط140، 1408ه

الشاشي القفال، محمد بن أحمد، حلية العلماء في معرفة مذاهب العلماء الفقهاء، الأردن: مؤسسة

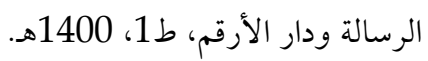

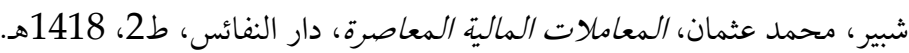
الشعراني، عبد الوهاب بن أحمد، الميز/ن الشعرانية المدخلة لجميع أقوال الأئمة المجتهجين ومقلديهم في الشريعة المحمدية (الميز/ن الكبرى)، دار العلم للجميع، ط1.

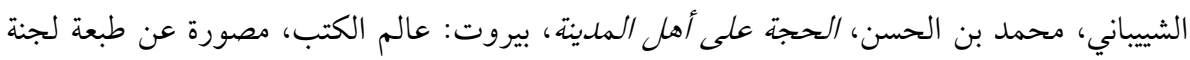

$$
\text { إحياء المعارف النعمانية. }
$$

الصنعاني، عبد الرزاق بن همام، المصنف، بيروت: المكتب الإسلامي، ط2، 1403هـ.

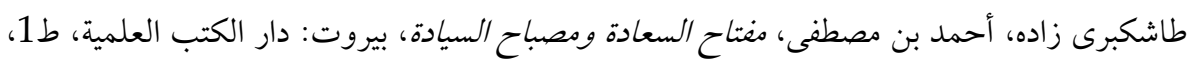
.1405

الطبراني، سليمان بن أحمد، المعجم الأوسط، القاهرة: دار الحرمين، 1415هـ.

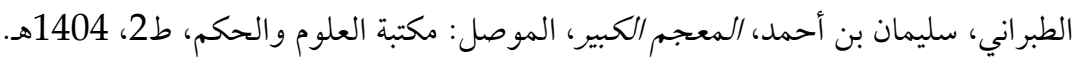

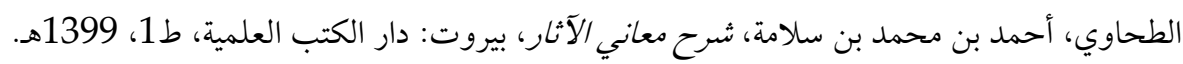

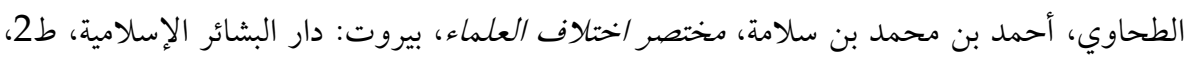
1417 هـ

عبد الحميد، أحمد مختار، معجم اللغة العربية المعاصرة، عالم الكتب، ط1، 1429هـ / 2008م.

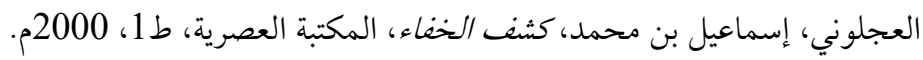
العراقي، عبد الرحيم بن الحسين، تخريج أحاديث الإحياء، الرياض: دار العاصمة للنشر، ط1، 1408هـ العروسي، خالد، الترُّْص بمسائل الخلاف ضوابطه وأقوال العلماء فيه. الغزالي، محمد بن محمد، إحياء علوم الدين، بيروت: دار المعرفة.

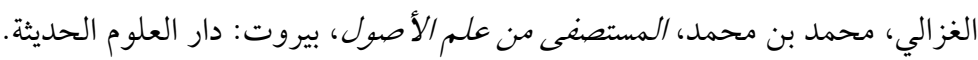
الغزنوي، عمر بن إسحاق، زبلة الأحكام في مذاهب الأئمة الأربعة الأعلام، مؤسسة الريان، ط1 مجا، 2001 الفيروزآبادي، محمد بن يعقوب، القاموس المحيط والقابوس الوسيط الجامع لما ذهب من كلام

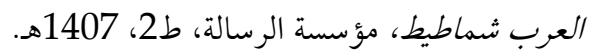
الكاكي، قوام الدين محمد، عيون المذاهب الكاملي في فروع المذاهب الأربعة.

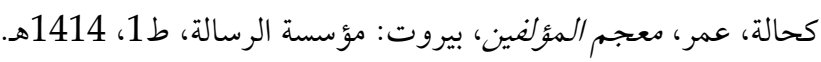


اللكنوي، محمَّد عبد الحليم، قمر الأقمار على كثف الأسرار على المنار، بولاق: المطبعة الأميرية، 1316هـ

المجلس الأعلى للشؤون الإسلامية، موسوعة الفقه الإسلامي المصرية، القاهرة، 1386هـ. مرتضى الزبيدي، محمد بن محمد بن الحسيني، إتحاف السادة المتقين بشرح إحياء علوم الدين،

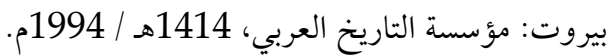

المروزي، محمد بن نصر بن الحجاج، اختلاف الفقهاء، الرياض: أضواء السلف، ط1 ط1،

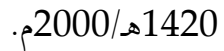

مسلم، مصطفى، مناهج المغسرين، دار المسلم، ط 1، 14: 1410هـ . المطرزي، ناصر بن عبد السيد، المغرب في ترتيب المعرب، دار الكتاب العربي.

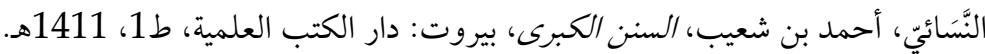
اليافي، عبد الله بن أسعد، مرآة الجنان وعبر اليقظان في ما يعتبر من حو/دث الزمان، مؤسسة الأعلمي لئي للمطبوعات، ط1، 1970، 1970م. 